ENCONTROS PROVÁVEIS: A PALETA E A PENA 

ENCONTROS PROVÁVEIS: A PALETA E A PENA

Filomena Vasconcelos

Isabel Pereira Leite

Biblioteca Digital da Faculdade de Letras da Universidade do Porto 2021 


\section{FICHA TÉCNICA}

Título: Encontros Prováveis: a paleta e a pena

Autoras: Filomena Vasconcelos (pinturas) e Isabel Pereira Leite (textos)

Prefácio: Mónica Baldaque

Texto: Joaquim Pinto Machado

Posfácio: Maria Luísa Malato

Editor: Universidade do Porto. Faculdade de Letras. Biblioteca Digital Local e data de edição: Porto, 2021

ISBN: 978-989-8969-80-4

DOI: $10.21747 / 9789898969804 /$ enc

URL: https://ler.letras.up.pt/site/default.aspx?qry=id022id1746\&sum=sim

Capa: "Rosto", de Filomena Vasconcelos (técnica mista, 55 x $46 \mathrm{~cm}$ - 1998)

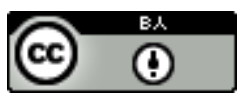




\section{SUMÁRIO}

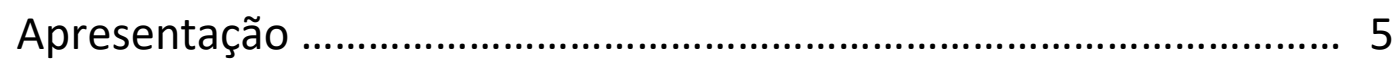

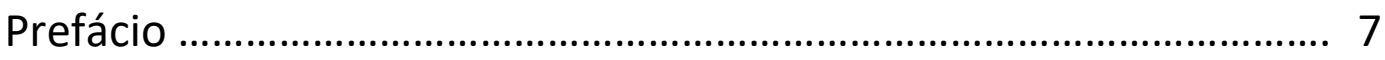

Encontros Prováveis: a paleta e a pena ................................................ 9

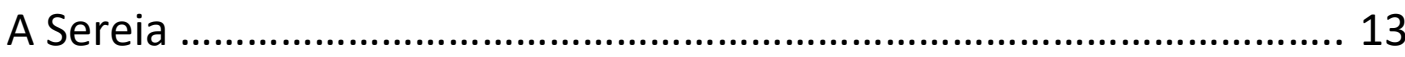

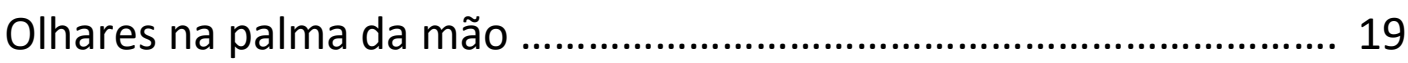

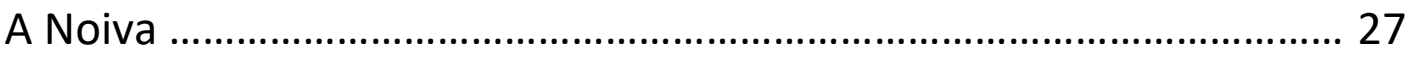

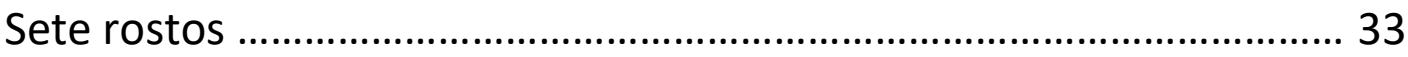

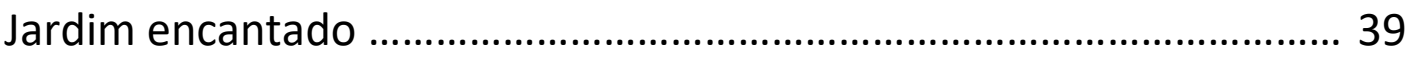

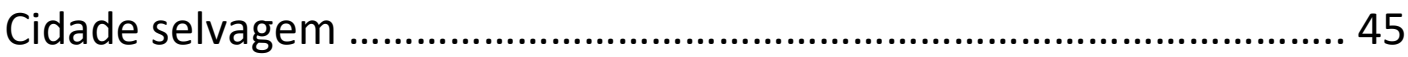

Histórias do dia e da noite ………………………….......................... 53

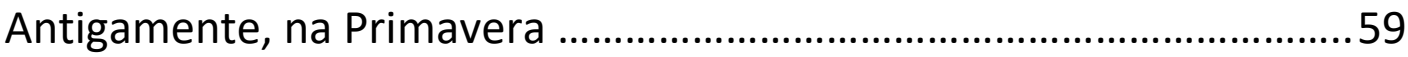

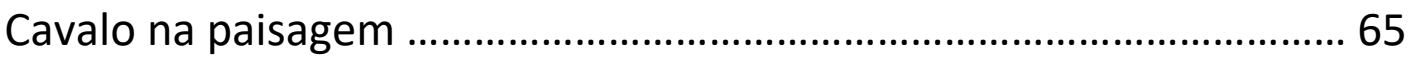

A Enigmática Ilha da Páscoa ................................................................. 71

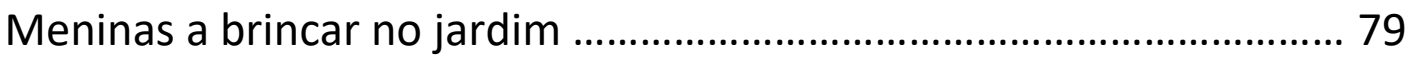

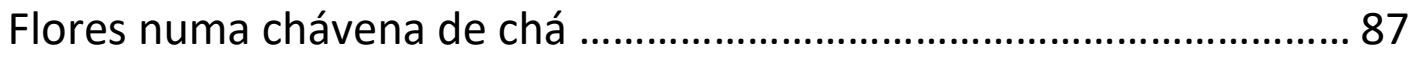

A Rapariga da libelinha ……………........................................................93

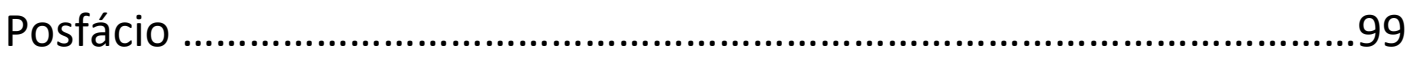





\section{APRESENTAÇÃO}

Encontros prováveis pode havê-los não só n' O Labirinto da Saudade, que pertence a Eduardo Lourenço, mas, por exemplo, também nos labirintos de uma Faculdade.

Dia após dia, mês após mês, ano após ano, cruzamo-nos com gente que imediatamente identificamos e, com toda a certeza, afirmamos conhecer. Mas, será isso verdade? O que é conhecer alguém, alguém que faz parte de todos esses que são, para nós, os outros?

É aos outros que por cá passaram e viveram e aos que, perto ou longe, connosco vivem que quase tudo devemos e, afinal, o que sabemos nós deles? E o que sabem eles de nós?

Ao longo de mais de vinte e cinco anos, duas pessoas partilharam o mesmo espaço, cruzaram-se milhares de vezes, trocaram palavras de ocasião e, até, em certas alturas, ofereceram um pouco mais do seu tempo a uma ou outra conversa agradável.

Simplesmente, ainda não se conheciam. Não sabiam que uma pintava e outra escrevia e que o faziam mais ou menos "clandestinamente". Quase ninguém conhecia essas facetas que as duas cultivavam há tanto tempo.

Na verdade, não se conhecendo, apenas sabiam quem era uma e quem era outra. Mas o ser humano é um todo - corpo e alma, sendo que só com muita alma chega a pegar num pincel ou numa caneta para dar um pedaço de si próprio aos outros.

Foi, pois, a partir de um certo dia de Verão de 2008 que os encontros prováveis se transformaram em encontros de cumplicidades que se foram descobrindo e dando lugar a uma ideia que ganhou lanço, tomou forma e se encheu de conteúdo.

Os Encontros Prováveis passaram, então, a ser encontros felizes entre $A$ Paleta e a Pena.

Este livro foi pensado para ser editado em 2008. Por vicissitudes várias, não chegou a sê-lo. 
Todavia, os 13 Encontros Prováveis acabaram por ser originalmente publicados em sucessivos números de "As Artes Entre as Letras", entre Outubro de 2019 e Dezembro de 2020.

A gratidão que sentimos, por termos sido acolhidas com tanta benevolência pela Directora desta publicação, que desde cedo se tornou uma referência no panorama cultural português, continua viva.

O texto de Joaquim Pinto Machado é inédito. Foi escrito em 2008, com o propósito de ser incluído no livro que nunca existiu.

Nada acontece por acaso. O que Joaquim Pinto Machado escreveu, como primeira testemunha do resultado destes 13 Encontros, fica aqui registado, apesar de já não se encontrar entre nós. Nunca saberemos se, 13 anos volvidos, diria o mesmo. Todavia, a eterna generosidade das suas palavras permanecerá. Muito nos orgulha que nos tenha dedicado um pouco do seu Tempo.

O prefácio e o posfácio, que surgem agora, foram pensados para a presente edição.

Mónica Baldaque e Maria Luísa Malato, a quem ficamos profundamente gratas, aceitaram o pedido que lhes dirigimos. É uma honra que nos deixa sem palavras, porque, quando nos pareceu que, através de uma paleta e de uma pena, talvez fosse possível exprimir algo que extravasasse o nosso quotidiano, nunca imaginámos o que viria a ser o percurso que então encetámos.

Porto, Abril de 2021

Isabel Pereira Leite 


\section{PREFÁCIO}

\section{Quatro andamentos}

Filomena sentou-se no banquinho de pedra da janela que dava para o jardim. A almofada vermelha combinava com a cor laranja do vestido de lã; o traço preto que contornava a sua figura extática, isolava-a da atmosfera imprecisa da salinha, como se a mantivesse numa espécie de prisão de cor, de silêncio, de conforto.

Era Inverno, um meio da tarde já escura, e Filomena pousara o livro que estava a ler no outro banquinho de pedra, à sua frente. Esse, não tinha uma almofada vermelha, e um traço preto contornava o livro, impedindo-o de cair ao chão, ou de poderem ser voltadas as suas páginas.

Filomena olhava o jardim e as suas sombras. Olhava-se a si, reflectida no quadrado de vidro da janela. A sebe de buxo estendia-se por um caminho tão longo, tão longo, que só a música de Arvo Part a acompanhava, até se extinguir.

Era Outono, um meio da tarde perfumada e triste, e Filomena estava sentada num degrau, com uma dália lilás no colo. Uma chávena de chá, vazia, pousada a seu lado. O vento morno que soprava, e baloiçava as longas folhas da nogueira, onde nas linhas regulares se escreviam pensamentos e recados, não lhe agitava os cabelos, porque o traço preto que a envolvia, a separava dos sons e dos ventos. Filomena com a chávena de chá, ficavam enclausuradas dentro dessa fita de um negro espesso, e apenas via, à sua frente.

Era Verão, um meio da tarde de fruta madura, acerolas vermelhas com pequenas histórias enroladas, histórias de Espanha, de guerra e de santos, e Filomena dormia no chão de saibro e espinhos de roseira. Passavam a seu lado cabeças desconhecidas, que olhavam com grandes olhos de amêndoa, mas não a viam, porque o traço negro que a recortava no chão, era como uma linha de tempo. Mágica. 
Filomena dormia descalça, e os dedos dos pés eram azuis, e entre eles cresciam as flores azuis das escadas de Jacob. E ela dormia, sem sonhos, que é o dormir das flores.

Era Primavera, e a essa hora de nada, que é a hora da tarde, em que o respirar custa, e as lágrimas são verdes, ou de outra cor qualquer, Filomena, com um vestido de noiva quase branco e rosa fúcsia, saltava os quadrados do jogo da macaca, e tudo era envolvido numa fita negra, baça, que se ia desenrolando, desenrolando, até se soltar dos vitrais que contavam a sua história, e voar até ao sol. Os olhos grandes de Filomena fixaram com espanto o sol, e os olhos grandes do sol, fixaram com espanto Filomena.

E ouviu-se...Silentium, (de Arvo Part.)

Mónica Baldaque

Gólgota, 28 de Março de 2021 


\title{
ENCONTROS PROVÁVEIS: A Paleta e a Pena
}

\author{
de \\ Filomena Aguiar de Vasconcelos (Pinturas) \\ e \\ Isabel Pereira Leite (Narrativas)
}

1. Deve-se à amizade "respeitosa" (dada a diferença de idades) de Isabel Pereira Leite e à confiança que Filomena Aguiar de Vasconcelos Ihe tributa, o pedido de que eu prefaciasse este livro. A amizade, se autêntica, muitas vezes exagera as capacidades do amigo e até lhe atribui as que ele não tem, e a confiança pode levar a anuências imprudentes.

Vem isto em jeito de justificação para o facto de começar o meu depoimento dizendo o que sou e ao que venho, não vá alguém supor que sou o que não sou e que venho ao que não venho.

Não sou perito em literatura e muito menos em pintura, pelo que não venho apresentar uma apreciação técnica das expressões de uma e outra nesta obra. Sou apenas um dos destinatários destes "Encontros Prováveis" - o primeiro, por ordem cronológica - que serão postos à disposição do público em geral. Como tal, é com toda a legitimidade que venho dizer como vi e como li e o que me ficou depois. O que fica depois é importante porque é ele que traça o destino do exemplar que possuímos: ou sepultura ou ulterior reanimação.

2. Começo por referência às pinturas de Filomena Aguiar de Vasconcelos, não por ser terreno que pise com menor insegurança antes pelo contrário - mas porque foram elas a chave do motor de arranque que pôs em andamento a elaboração desta obra.

Para mim, pintura, era só a figurativa, tendo na vanguarda os génios renascentistas, só ultrapassados em sintonia afectiva quando me encontrei, face a face, com os génios do impressionismo.

A minha relação com a pintura "esquisita" começou por repúdio, tal como me tinha acontecido com a cerveja. Mas enquanto que, com 
esta, a relação se inverteu logo que chegou o hipertérmico Verão seguinte (a propósito, para onde anda ele fugido?), o meu apreço pela pintura "esquisita" (peço desculpa de manter o termo, mas para mim é o melhor e estou certo que será compreendido pelos leitores analfabetos em pintura como eu) desenvolveu-se mais tardiamente e mais lentamente, em sincronia com o meu andamento no caminho da investigação científica em que com gosto avançava por imperativos académicos.

O elo de ligação entre essa tal pintura e a atitude de investigação científica era a questão dos "quês" e dos "porquês". Na pintura "esquisita" era a sedução de descobrir o que aquilo representava, do porquê dessa representação e da mensagem nela codificada.

A pintura "Sete Rostos", a quarta destes "Encontros", é um bom exemplo disso.

Começando logo pelo título: porquê explicitar que são sete, e não o limitar a "Rostos"? Pelos vistos, é importante precisar que são sete. Isto até me levou, confesso, a entendê-lo como astúcia feminina a induzir o observador a contá-los, o que o obrigará a observação atenta, pois a tarefa não é fácil... E sete, porquê? Por que não só seis ou oito? Sete, por, segundo a Bíblia, ser um número perfeito? Pensando bem, a palavra sete no título não deve ser isca para atrair a atenção mas é importante em si mesma para a interpretação da pintura. E porquê rostos de perfil, excepto um, que está quase tapado por outro? Aliás, o mesmo sucede com todos: tapam-se em grande parte uns aos outros. Porquê? Tudo isto faz sobressair a questão fundamental, o grande desafio ao observador: o do significado, o da mensagem, afinal o da razão originária de ter sido pintada esta pintura.

Por isso, por ser a questão por excelência, ouso apresentar algumas hipóteses (aliás, é por aqui que se começa na investigação científica): unidade da família humana na diversidade das pessoas? máscaras que as pessoas usam por medo, vaidade ou manha? diferentes expressões que uma mesma pessoa manifesta consoante as emoções que a agitam? esbirros de um qualquer "Big Brother" de um qualquer regime totalitário? enigma da vida e apelo a que cada um busque o seu "rosto", o assuma e rejeite outros, porventura mais sedutores, mas que não são o seu? - "Não, não vou por aí" (Régio).

3. As narrativas de Isabel Pereira Leite são a sua resposta a estas interrogações de quês e porquês, suscitadas por cada uma das 13 
pinturas de Filomena Aguiar de Vasconcelos. Muitas delas, todas elas, tendo na pintura em causa o seu ponto de partida, a certa altura libertam-se, ganham dinamismo determinista intrínseco, autonomizam-se, subsistem por si próprias e, chegadas ao fim, reencontram o ponto de partida.

São curtas, leves e diáfanas como claras em castelo no seu correr, mas consistentes e densas pelo realismo das emoções que brotam da identidade humana e fervem à tona da sua condição, emoções belamente "pintadas" por fecunda, ágil e deliciosa imaginação.

A narrativa despoletada por "Sete Rostos", a que me referi, é excelente exemplo do que acabo de dizer. Para Isabel Pereira Leite eles, esses sete rostos, são "A Casa", e "A Casa tem um nome. A Casa é o Mundo".

4. As narrativas de Isabel Pereira Leite não teriam existido se as pinturas de Filomena Aguiar de Vasconcelos não tivessem existido primeiro. A "alma" (o sentido) de cada uma das pinturas de Filomena Aguiar de Vasconcelos ficou dilatada pela narrativa correspondente de Isabel Pereira Leite. Uma e outra, Filomena e Isabel, reciprocamente co-autoras: expressão exemplar, no domínio artístico, do fenómeno biológico da simbiose. Paradigma excelente da relação que deveria imperar no interior da comunidade humana: então, sim, o Mundo seria verdadeiramente "A Casa", a casa de todos.

Eis o que, de essencial, me ficou. Por isso é obra que relerei e reverei muitas vezes.

Joaquim Pinto Machado

Porto, 16 de Outubro de 2008 

A SEREIA 



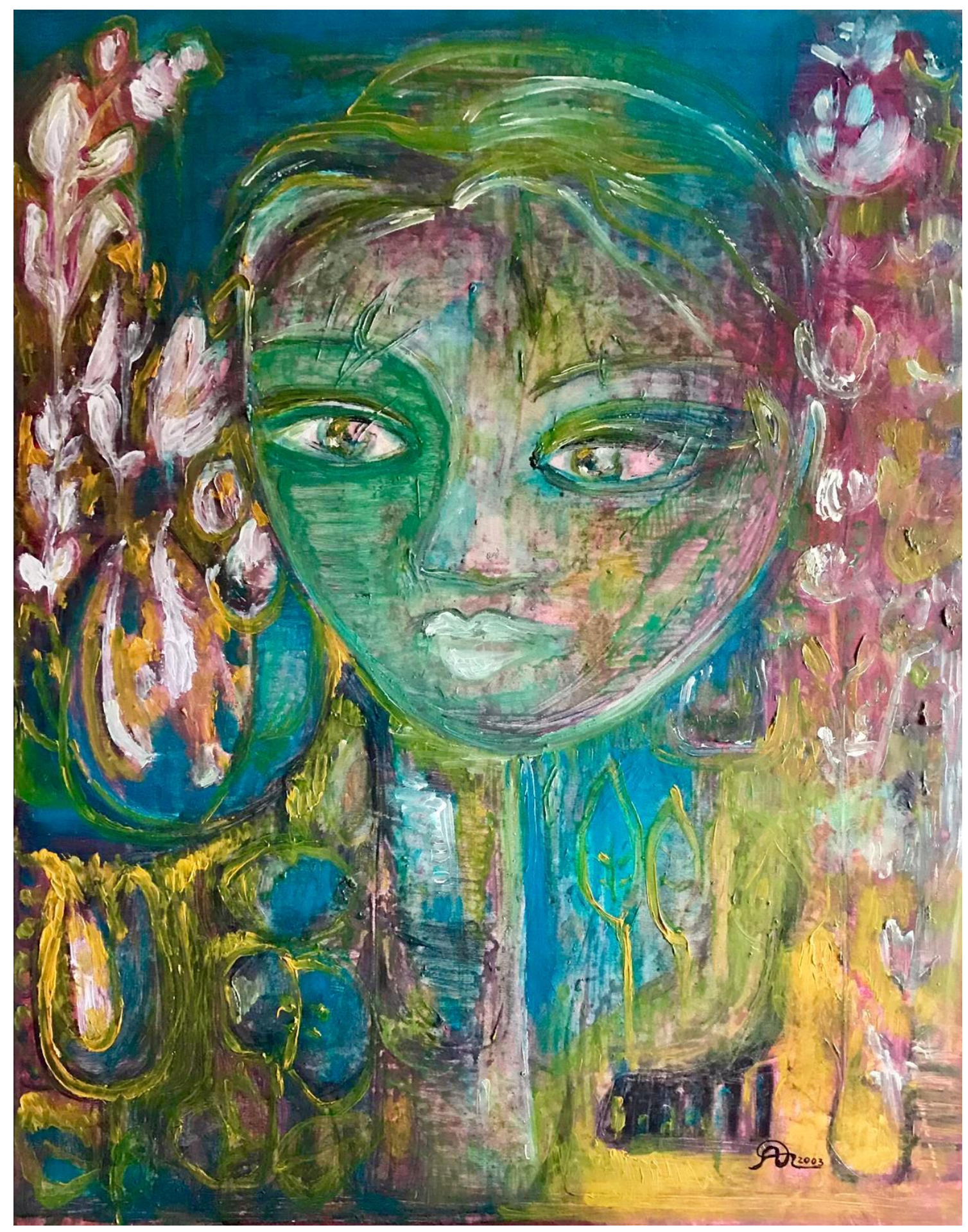

Óleo s/ tela 92 x 73 cm - 2003 

Brandamente, a Sereia acordou. Era bom viver nas profundezas, onde as cores difusas mudavam a cada instante e onde o enorme recife de coral lhe garantia nichos de conforto.

Acordada, passeou o olhar por esse espaço onde poucos humanos se atreveriam a penetrar. Tudo lá estava como na noite anterior (noite e dia, aliás, confundiam-se) e como constantemente lhe surgia nos sonhos.

Era sobretudo deles que a Sereia retirava com que alimentar a sua ânsia de vida. O mundo em que vivia assemelhava-se, aos seus olhos doces, ao mundo dos sonhos que a embalavam. Ou seria ao contrário? Ela só se sabia íntima desse lugar misterioso, no qual o próprio tempo parecia, por vezes, querer suspender-se, como que abandonado à sua sorte, já que nenhum homem visitava aquele sítio.

A Sereia, animada pelos sons do quase silêncio à sua volta, pôs-se a imaginar, para lá da sua aparente solidão, todos esses ninguéns que partiam e chegavam a cada passo. Seria assim tão diferente deles, daqueles que viviam perto do céu e das estrelas, que sentiam o vento, a chuva, o sol, que percorriam caminhos distantes?

Insondáveis são os desígnios da Criação. Porém, e apesar dessa crescente nostalgia de algo que mal lhe era dado conhecer, nas suas veias circulava a seiva ardente de quem anseia por mais do que a vida que conhece. Nesses momentos, era como se a alma acordasse para uma outra contemplação, seguindo o apelo de uma voz maravilhosa e cálida.

A essência do perfume do fundo do mar invadiu-lhe os sentidos e a Sereia pôs-se à escuta.

Era o momento que precedia o encontro feliz que acontecia uma vez no ano, no equinócio da Primavera. O recife costumava abrir-se e os seus habitantes vinham cumprimentá-la, apreciadores, e perguntar-lhe que planos tinha para o dia. A Sereia gostava de atenção. A melancolia que dela sempre se apossava ao acordar, acabava por se ir transformando em placidez e os seus grandes olhos contemplativos tornavam-se ainda mais claros.

Colares do mais fino rendilhado, gargantilhas, braceletes e pulseiras talhadas por artistas dedicados, flores lindas criadas a pensar na bela e farta cabeleira de oiro da Sereia eram-lhe oferecidos com delicadeza.

O recife, ao contrário do que é comum, não era de coral rosado, mas de um azul esverdeado, o que o tornava raro e, naturalmente, cobiçado, se fosse descoberto.

O encantamento acontecia num espaço emocionado de lembranças suaves que mantinham a Sereia alheada daquela sensação inquieta que the 
pertencia: é que, no fundo de si mesma, sentia que uma parte do seu ser continuava por preencher. Era o amor que ela gostaria de abraçar, mas não sabia onde encontrar; era o amor, a grande esperança do seu coração, era o que, forçosamente, existiria no misterioso reino do outro lado do oceano. Todos os dias a sua alma se punha à escuta, mas a vastidão era grande demais para que pudesse apreender todas as mensagens que os sons the traziam.

Entre colares e flores, a Sereia ia imaginando o beijo que prometia a si mesma fazer prolongar para além de um momento, mesmo que fugaz, quando acontecesse.

As luzes constelavam a noite, suspensas sobre a quietude das águas. Os sons voavam, espantados pelo vento, por vezes entre brumas. Tudo prenunciava uma noite mais, mas o acaso, ou talvez não, tudo mudou, apenas porque alguém descobriu o recife.

Um mergulhador perdido acabou por dar com ele.

Foi tal o encantamento, que logo se Ihe varreram do pensamento as preocupações várias que a difícil situação em que se encontrava Ihe trazia. Que beleza, que paz, que mundo fascinante, que seres extraordinários, que misteriosa essa luz no fundo do mar!

Inconscientemente foi-se aproximando mais e mais, como quem não resiste a uma atracção poderosa.

Ah! Mas eis que avista uma criatura como nunca imaginara poder existir. Lentamente, a Sereia olhou, e naquela figura estranha, igual a coisa nunca vista ou imaginada, fixou os seus enormes olhos de água.

O mergulhador aproximou-se e a Sereia, porque tudo nela o buscava, estendeu a mão para o tocar. Correspondendo ao convite, ele ofereceu-lhe, por sua vez, a mão.

Mas foram os olhos, mais do que as mãos, que os prenderam um ao outro. Celebrando, como se em júbilo cantasse um hino, a Sereia entregou-se ao sabor do momento pelo qual há tanto tempo ansiava...

P. S. O fundo do mar, a sereia e o mergulhador, com Sophia por perto. Sempre... 
OLHARES NA PALMA DA MÃO 



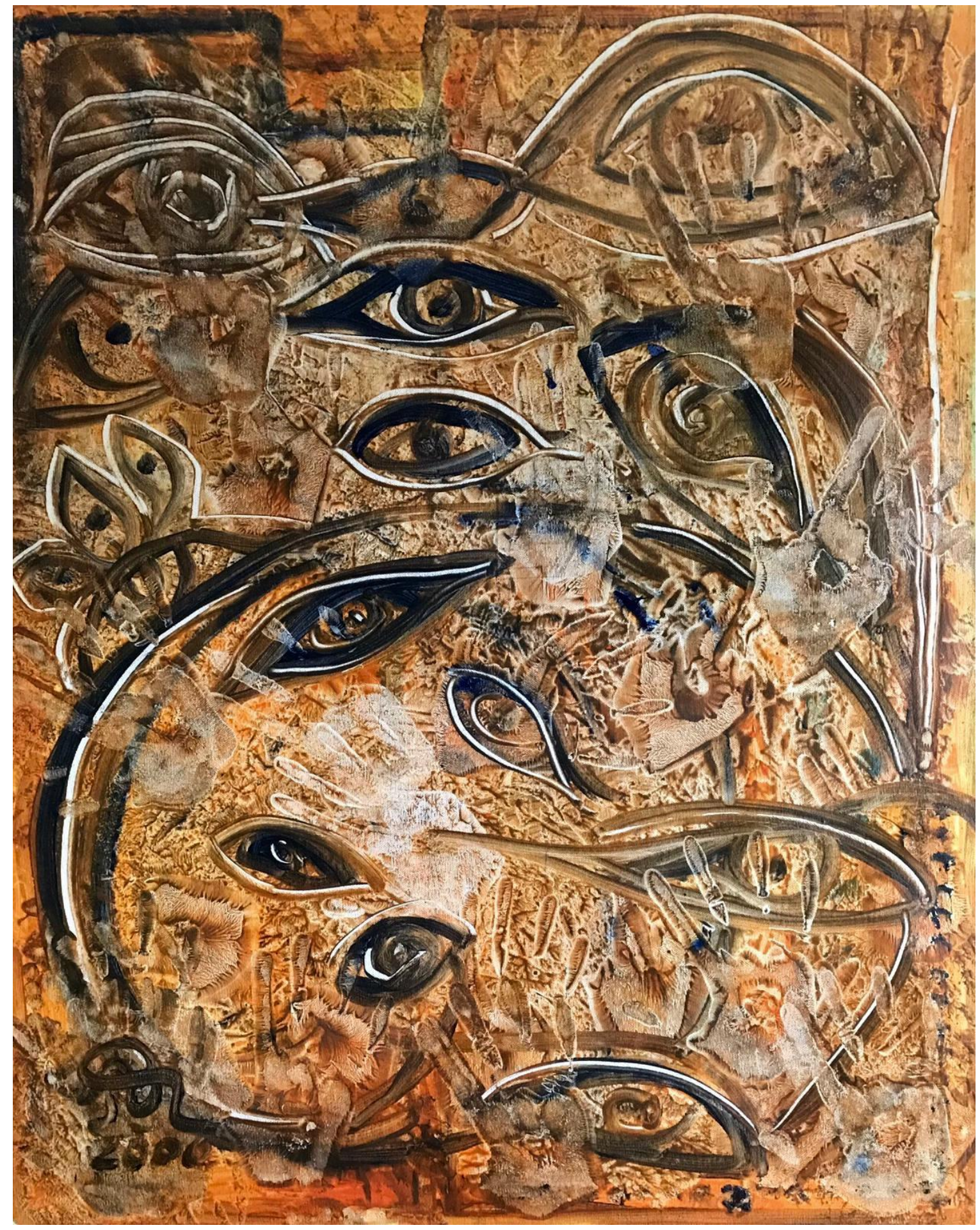

Óleo s/ tela 82 x 66 cm - 2000 

Aproximou-se da porta, e devagarinho, encostada à parede, entrou.

Hesitante, foi olhando em volta, até que o viu. Ali estava ele, impávido e sereno, senhor de si, dominando a sala com toda a sua altura. Ela, receosa, não se decidia a olhá-lo de frente. Ele aguardava-a, simplesmente. Mas por que é que tinha entrado? Que força era essa que a atraía como poucas?

Lembrava-se bem do primeiro encontro. Há tantos anos, tantos! $\mathrm{E}$ daí...talvez nem tantos assim. Afinal, sempre tinha existido aquele espaço enorme, aquela Casa de todos, onde em cada Setembro se encontravam e onde, naquele ano, tudo tinha acontecido.

Era um dia calmo, sereno, dourado. O grande castanheiro do jardim anunciava fartura, mas eram as folhas no chão que lhe despertavam o interesse. Costumava juntá-las como quem faz leques e perder-se naquele enleio, seguindo percursos ao acaso, até acabar por ouvir alguém chamar por ela.

Naquele dia, a manhã acordara molhada e a Avó tinha dito "Hoje ninguém vai lá para fora. Não me parece que a chuva vá parar."

Mafalda, entrevendo o grande castanheiro fustigado pela água que o vento empurrava, mirava-o com tristeza e olhava as folhas caídas em volta, cada vez mais molhadas.

"Não arranjas nada com que te possas entreter, Mafalda?". "Não, Avó, só me apetece olhar lá para fora, estar à janela; não consigo tirar os olhos do castanheiro! Não sei, é como se estivesse a despedir-me dele..."

O dia continuou na sua lentidão especial e Mafalda não se afastou da janela até que escureceu.

Foi uma noite arrepiante. O ribombar dos trovões não cessava e tudo parecia tremer em redor. Rezava-se a Santa Bárbara, e cada um ao seu Anjo da Guarda; a Avó dava o mote e o Terço lá ia sendo desfiado. O sono chegava e uns e outros recolhiam aos quartos, esperando pela bonança que, certamente, o dia seguinte traria.

Na verdade, a bonança chegou; todavia, com ela, também, uma triste surpresa: o castanheiro centenário que a tanto assistira já, tinha sido atingido por um raio e jazia, decepado, onde antes se impunha como dono e senhor do seu espaço.

Mafalda não se conteve e deixou que as lágrimas lhe invadissem a alma. Chorou, como se chora pelo nosso melhor amigo. A Avó, de longe, ia observando, sem nada dizer. Deixou que aquela expansão de tristeza se 
fosse diluindo, embora, conhecendo a neta como conhecia, soubesse que aquela dor havia de permanecer com ela.

Os anos passaram, uns mais depressa do que outros. Mafalda foi definindo rumos na vida, mas a solidão que sentia sempre que voltava àquela Casa, tolhia-a e ensombrava-lhe a memória.

Até que um dia, a Avó Ihe disse "Vem cá, Mafalda! Acho que chegou o momento!" Abrindo a porta, fê-la entrar numa sala onde pouco se costumava ir. Encostada a um grande cavalete, estava uma enorme tela; ao lado, uma paleta, pincéis e bisnagas de tintas de várias cores, um retalho velho de pano e uma lata. "Tudo isto veio propositadamente para ti. Acho que sabes por quê."

Mafalda não se mexeu, apenas olhou longamente a Avó e ali ficou, no meio da sala, como quem tenta chamar o que passou para o outro lado da memória. Mas em vão. A memória não respondia ao apelo. Assim se passaram alguns dias até que Mafalda se atreveu a pegar nos pincéis. Aproximando-se da tela, acariciou-a. E, fechando os olhos, deixou-se transportar até àquele dia último que passara, cúmplice, à janela.

Abriu a primeira bisnaga e apertou-a sobre a paleta; depois, fez o mesmo à segunda e à terceira e o primeiro traço surgiu na tela. A partir daquele momento, o mundo parou para ela. Dentro daquela sala, o tempo deixou de correr. la já alta a noite, quando Mafalda sentiu a Avó junto dela. Não houve palavras, apenas um abraço profundo, sentido, um abraço em que se encerrava tudo aquilo que nunca havia sido dito. Foi também nessa noite que a Avó desapareceu para sempre.

Mafalda tinha-se tornado pintora. Pintava emoções, desejos, intimidades, sentimentos, sempre com um toque de nostalgia que deixava adivinhar um percurso atravessado por uma marca indelével. Jamais tinha pintado uma árvore e nunca o Outono estava presente nas suas composições.

Era esse o segredo que só a Avó conhecia: a mágoa de quem se vê, de repente, sem raízes, as raízes que nos prendem a lugares que são lugares de partilha nos quais outros viveram e hão-de viver. Pela mão da Avó, Mafalda reencontrara-as, para logo as perder de novo.

A tela permanecera no mesmo sítio, por expresso desejo de Mafalda. Não queria expor-se dessa maneira transparente; tinha receio que the entrassem na alma, lha perscrutassem e ficassem a conhecer o que sempre lhe estivera no íntimo e tivera vontade de guardar para si. 
Preparava-se a exposição que marcava os 25 anos da carreira de Mafalda. Os críticos, muito críticos, anunciavam um "dejá vu", os menos críticos, tidos por aqueles como ignorantes, mostravam-se na expectativa, mas sobretudo diziam todos mal uns dos outros, como de costume. Mafalda nunca lhes tinha dado demasiada importância.

la a caminho da Casa Grande. Pensava em tudo quanto tinha realizado e naquilo que tinha ficado por concretizar. Pensava, sobretudo, na Avó que tinha perdido, na falta que lhe fazia e no segredo que haviam partilhado. Parou o carro, ao chegar, e saiu devagar, contornando-o em passos sem pressa. Subiu as escadas de pedra e abriu a pesada porta. Foi avançando como quem avança receoso e hesitante. Empurrou mais uma porta, devagarinho, e, timidamente, apoiada à parede, esboçou um primeiro olhar rápido e não muito certo. Mas, sim, eram eles... Olhou-os de frente, olhou para o grande castanheiro da sua infância e juventude e para a pessoa que via ao lado dele, doce e firme. E sentiu, finalmente, que a alma se lhe abria!

P.S. Pearl Buck escreveu "A Velha Árvore". Lembro-me tão bem do prazer que senti ao ler essa história tão bonita. 

A NOIVA 



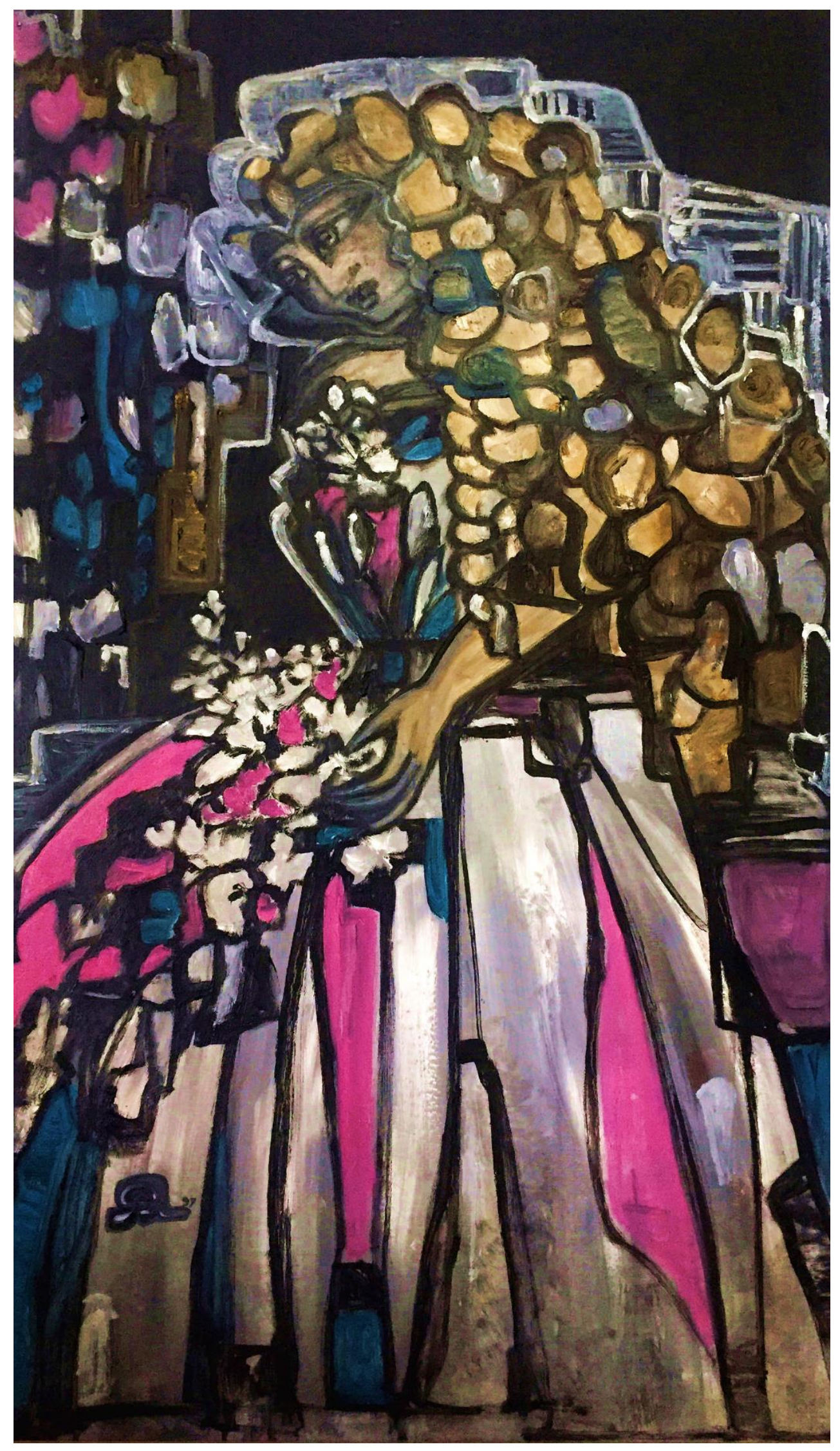

Técnica mista s/tela 100 x70 cm - 1997 

No adro da pequena Igrejinha, no qual se tinha improvisado um altar, estavam sentadas, em bancos corridos e alinhados, cerca de trinta pessoas.

Esperavam. Esperavam que começasse a cerimónia para a qual cada uma tinha sido convidada, de forma original, pelos noivos, um mês antes.

Entre amáveis sorrisos e sussurros simpáticos, aguardavam que chegasse o padre, o noivo e a noiva. O quarto de hora da praxe já tinha passado sem sinal algum de que pelo menos o padre e o noivo estivessem por ali.

O que as intrigava era aquele rapaz de olhos claros e luminosos, de cabelos um tanto ou quanto despenteados pela leve brisa que soprava e de t-shirt azul com uma pequena frase vagamente conhecida: "I'm in Heaven..."

Quem seria? E porque é que não se sentava e teimava em continuar em pé, junto dos três degraus que levavam ao altar? Não parecia nervoso; pelo contrário, embora o ar fosse meio tímido, mostrava-se tranquilo. Era a tranquilidade de quem tem a certeza de que o melhor ainda está para acontecer.

Tinha razão. A noiva acabava de chegar. Linda, tão linda que ele deu graças a Deus por ter enfiado aquela t-shirt.

Serena e como que deslizando, a noiva sorria, de forma velada, enquanto avançava. Só tinha olhos para o noivo e refreou o ímpeto que sentia de correr de encontro àqueles braços estendidos, irrecusáveis, que sempre tinham sido para ela como um oceano de tranquilidade, desde que os encontrara. Aqueles braços que tão bem Ihe sabiam quando dançavam juntos.

Fora a passear, junto ao mar, num belo entardecer de Setembro, que se tinham encontrado pela primeira vez.

Ele ia andando e atirando para longe um pequeno galho que 0 companheiro, invariavelmente, corria a apanhar para lho trazer de volta. Ela compunha, na cabeça, uma peça de piano, e, de vez em quando, fechava os olhos imaginando-se no seu estúdio de paredes de vidro, de onde gostava de apreciar as ondas, sempre diferentes, de manhã à noite. Enquanto ele, distraído, olhava o entusiasmo do companheiro, ela, de olhos semicerrados progredia na melodia. Cruzaram-se sem se terem visto, mas algo de indefinido ficou no ar a pairar, porque, de repente, Noname (o nome do cão que ainda era aparentado com um outro conhecido de um tal Nuno Júdice) estacou, largou o galho da boca e ficou a olhar para Íris. 
A rapariga tinha o nome da musa de Wim Mertens, de quem, por acaso (mas será que haverá acasos?) o rapaz também gostava. Noname e Wim Mertens foram, pois, quem primeiro os ajudou a desatar as palavras. Depois vieram outras palavras, vieram as melodias, as muitas melodias, e depois veio o dia.

O dia em que descobriram a Igrejinha românica em ruínas, no meio de um planalto carregado de verdes de onde, ao longe, se avistava o mar.

Íris apontara-lhe a t-shirt e ele sorrira. Era o lugar perfeito. Seria ali, sem dúvida, que haveriam de se casar e de juntar, para que pudessem testemunhar a sua irreprimível alegria, aqueles de quem mais gostavam.

E o dia chegara, prometendo sol temperado e a calma das horas que passam devagarinho.

Como devagarinho Íris avançava, pensando que só mesmo ele seria capaz de a aguardar ali com aquela t-shirt que, num dito de nada, tudo dizia: "I'm in Heaven..." Era assim, também, que ela própria se sentia, quando ele a tomava nos braços e dançavam sem parar. No momento em que lhe deu a mão para que juntos subissem os três degraus até ao altar, conseguiu repetir-lhe baixinho: "Heaven, I'm in Heaven..." e foi então que o coro, que até aí passara despercebido, se lhes uniu e continuou: "And my heart beats so that I can hardly speak, And I seem to find the hapiness I seek, When we're out together dancing cheek to cheek..."

O padre, aparecido de repente nem se percebia de onde, mostrava um ar benévolo, apesar de ser difícil distinguir-lhe bem as feições. Parecia encher todo aquele espaço, embora nem sequer tivesse ainda pronunciado uma palavra.

Coincidência (ou não!) trazia vestida uma t-shirt com pequenas nuvens estampadas e uma curiosa palavra, mais ou menos a meio, um tanto desviada para o lado esquerdo: GOD.

Assim, de um momento para o outro, era como se finalmente todas as notas da mais bela sinfonia se tivessem juntado!

Foi então que Íris acordou e pensou: "Heaven can wait..."

P.S. Para Nuno Júdice, Wim Mertens e Irving Berlin o meu muito obrigada! Estão muito próximos de mim! 
SETE ROSTOS 



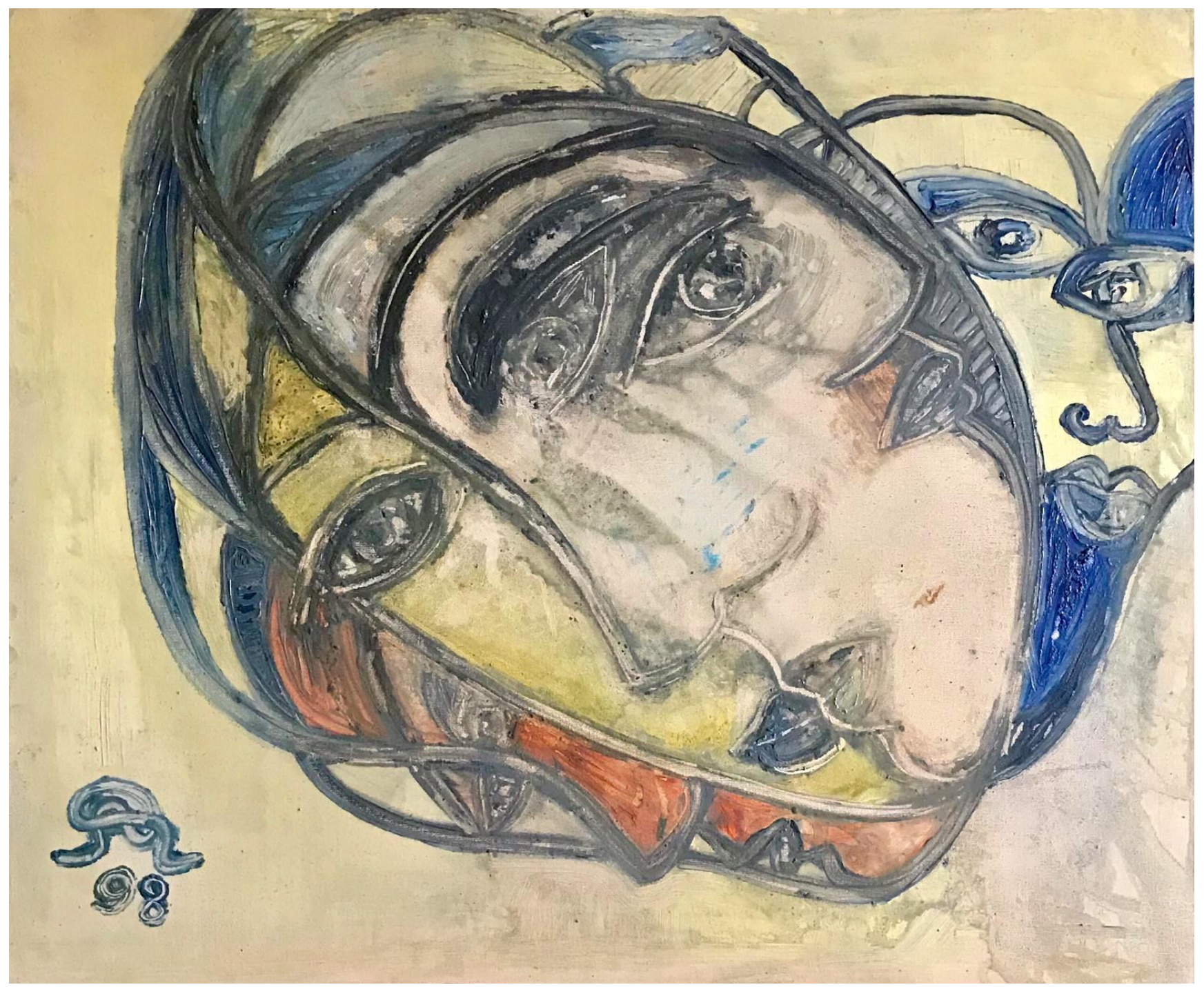

Óleo s/ tela 50 x $60 \mathrm{~cm}-1998$ 

A Casa tem Alma, sentimentos. E os sentidos despertos.

Num primeiro olhar observa-nos, enquanto nos abre a porta. Cedo, porém, o olhar se torna cúmplice, sem reservas, num sorriso franco que Ihe vem do que vai partilhando.

Há dias em que a Casa se veste de todas as cores e gosta de se rever no olhar de quem nela descobre a luz e a sombra. Nesses dias, a Casa cresce, porque tem dentro de si o mundo inteiro. Nesses dias, os sentidos estão em festa! Porém, há dias cinzentos, húmidos de chuva, dias que não fazem sentido.

A Casa deixa ouvir os seus sons: o som inaudível da muralha, o som imenso do sol, e também a alegria das vitórias e a mansidão das histórias contadas à lareira. $\mathrm{O}$ som da mesa de toalha branca, logo pela manhã, e o som da lembrança de um momento fantástico, no calor da noite. O som das lágrimas e o desalento dos profundos suspiros, a tristeza das derrotas e a revolta dos que se julgam perdidos.

A Casa tem cheiro, ou não. Cheira a pão generoso, a leite espumoso, a azeite cor de oiro, a louro, a hortelã, a canela, a especiarias refinadas, a chocolate quente, a mel espesso e escuro. Em cada canto se confundem os cheiros, porque a Casa é a Casa de todos os perfumes que nos entram no coração, nos aquecem a alma e nos alimentam. A Casa tem o cheiro de todos os que trazem consigo o cheiro da Vida.

Os sabores confundem-se na Casa. Sucedem-se as múltiplas viagens através da mesa farta do sabor das palavras que evocam outras paragens, e das portas que se abrem para outros lugares.

A Casa prova o que lhe vem dos quatro cantos da Terra e apura o paladar, porque todos os dias há sabores desconhecidos que se cruzam em iguarias fantásticas. Muitas vezes não há que provar e apenas a imaginação pode servir de consolo.

A Casa abraça-nos, timidamente, primeiro, depois com força, porque também nós somos um pedaço dela. A Casa agarra-nos, prende-nos, encanta-nos. No seu regaço sentimos que sempre nos há-de acolher.

$\mathrm{Na}$ sua pele luminosa há marcas de séculos e séculos de vidas que podemos quase alcançar. De repente, conseguimos avistar a Atlântida, envolta em azuis, estendendo os braços até conseguir, mansamente, tocar-nos. Para além dos nossos passos, há outros passos em direcção aos quais a Casa nos conduz.

$\mathrm{Na}$ Casa acorda-se e adormece-se em desfasamento constante, porque cada um tem o seu tempo próprio e exercita os seus cinco sentidos entre uma coisa e outra. 
São sete momentos, sete faces, de manhã à noite. Sete rostos nos quais se espelha o sentir e o viver sob um telhado que tanto pode resistir a qualquer intempérie, como ter já deixado que lhe voassem as telhas.

Dentro da Casa cresce a memória que ela guarda e preserva.

$\mathrm{Na}$ Casa vive-se como se lavra a terra: arado, enxada, semente, e muita dedicação. Sem agricultura, não há cultura e o que é a cultura senão o resultado da Vida que o adubo, em doses certas, fez crescer?

A Casa sente, porque vê, ouve, cheira, saboreia e tem pele. A Casa é intemporal, porque nela viveu uma moira encantada que, um dia, lhe deu um elixir a provar. A Casa acorda e adormece na certeza de que é Vida. Vida perene, breve ou precária, mas Vida com Alma.

A Casa tem um nome. A Casa é o Mundo.

P.S. Entre "Trecho" e "Pátria Minha", de Vinícius, à luz dos meus olhos há sete rostos... 
JARDIM ENCANTADO 



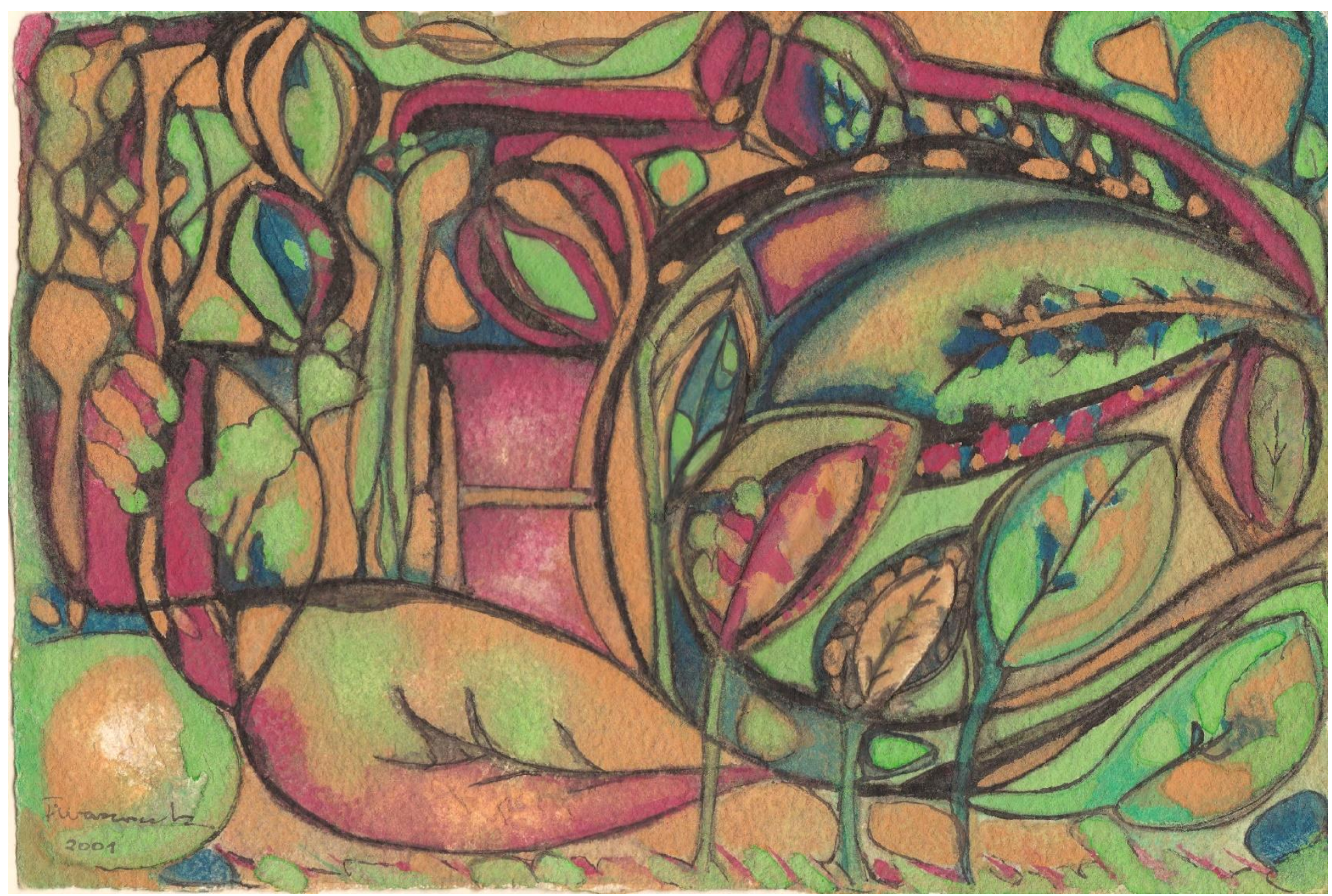

Aguarela s/ papel 21x 29,7 cm - 2001 

O jardim era esplendoroso. Descrevê-lo com palavras seria prestar-Ihe fraco tributo.

Ali estava a natureza na imensidão da sua beleza, na sua máxima prodigalidade, em toda a sua luxúria.

Num certo dia já longínquo, passeando descuidada por ali, a harmonia fixara-se naquele lugar, porque, na verdade, entendia que tinha de encontrar um poiso, um espaço para criar raízes. Encostara-se, em paz, às paredes daquele extenso muro de pedra e depois esticara-se, espreguiçando-se, tendo conseguido estender-se e preencher todo o espaço que encontrara.

Assim nascera aquele jardim único e de uma incomensurável beleza.

Ali descansava, agora, João, despreocupadamente esticado numa cadeira confortável, forrada com almofadas amarelas. Passava pelo sono depois de um almoço leve. O enorme guarda-sol branco protegia-o do calor que se teria tornado demasiado atrevido, se não fosse a leve brisa que soprava do mar.

O momento era, pois, perfeito. João sonhava com borboletas. Borboletas lindas, umas de cores suaves, outras de tons mais intensos, que batiam as asas sem parar numa conversa alegre e despretensiosa. Algumas, mais afastadas, parecia que cantavam como quem toca harpa ao longe.

Aqui e ali iam pousando, pedindo, com delicadeza, licença às flores para Ihes dirigirem a palavra. A maior parte destas não se fazia rogada; agradava-lhes vê-las dançar à sua volta e compreendiam que, de vez em quando, as borboletas precisavam de descansar e de dar dois dedos de conversa. Às flores sabia-lhes bem aquela corte que Ihes fazia crescer o ego.

João continuava a sonhar e, no meio do sonho, continuavam as borboletas em rodopio ou voo solitário, ora descansando, ora subindo mais alto, mas sempre, sempre ali por perto.

O sono tornara-se, entretanto, profundo. O livro que João tivera nas mãos acabara por resvalar para o chão. Apenas uma borboleta continuava, de flor em flor, em acrobacias elegantes. Era linda! Batia as asas devagar, num ritmo próximo da galanteria. Insinuara-se dentro do sonho com a certeza de quem se sabe capaz de prender a atenção do jardim inteiro, como se o fizesse sem intenção.

João admirava-a. Sentia-se completamente seduzido por ela. A graciosidade com que se movimentava na sua frente era extraordinária. Languidamente aproximava-se, para logo se afastar quando João estendia a mão. As borboletas conhecem bem as técnico-tácticas dos humanos! 
Seja instinto, seja acto condicionado ou reflectido o que as move, quem sabe se não são capazes de raciocinar, nem que seja só por micro segundos? Verdade, verdadinha, apesar de isto ser altamente improvável, o que é certo é que nunca se viu uma borboleta assumir a forma de um ser humano, mas que há seres humanos que gostam de se vestir de borboletas, disso é que não há dúvida. Convenhamos, pois, que qualquer coisa os atrai...

Mas voltemos ao sonho de João.

A bela borboleta acabara por lhe pousar na mão e ele, como se estivesse anestesiado, não tirava os olhos dela. Estava extasiado!

Assim se encontrava, nesse enleio embevecido, quando, de repente, sentiu uma ferroada na mão.

Na mão? Mas como, se era a formosa borboleta que ele via lá pousada? A dor fê-lo abrir os olhos. Qual borboleta, qual quê!

Era um enfadonho moscardo que lhe voava em frente ao nariz. Da cor, da luminosidade, da beleza, do delicado voo da borboleta, nem sombras. 0 que ali estava era um moscardo, decidido a picá-lo onde mais fosse possível.

Bzzz...Bzzz...Bzzz..., voava o moscardo. Não havia meio de conseguir desembaraçar-se dele.

Levantou-se, incomodado com o malfadado moscardo. João ia tentando afastar-se dele, mas quando este parecia desistir e simulava um afastamento, logo acabava por voltar à carga.

Era, decididamente, um moscardo determinado, persistente, mesmo petulante. De borboleta não tinha nada. Se o fosse, afastar-se-ia sensatamente, voando para longe.

João não sabia que cerca de um século antes, um certo Nicolai RimskyKorsakov, nesse mesmo jardim, se tinha sentido inspirado por outro moscardo que não desistia de lhe moer a cabeça: Bzzz...Bzzz...Bzzz...

Cento e tal anos depois, continuava a ser, seguramente, o mais célebre de todos os moscardos do mundo!

P.S. A Rimsky-Korsakov, os meus agradecimentos! 
CIDADE SELVAGEM 



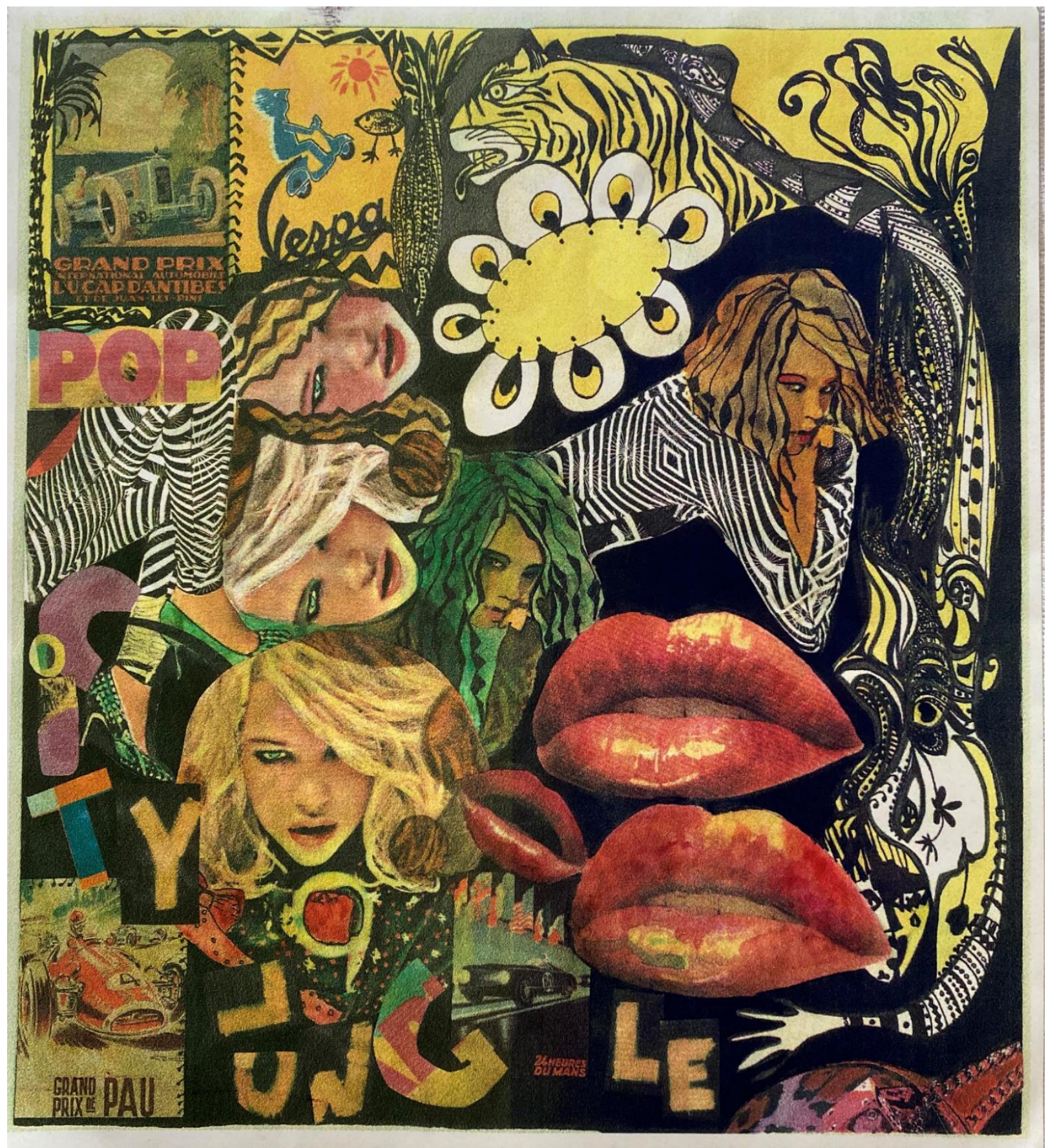

Técnica mista 55 x $65 \mathrm{~cm}-2003$ 

A Vespa avançava, rente ao passeio, não muito depressa. Maria evitava andar de carro nas pequenas deslocações que fazia diariamente.

A cidade era uma selva, cheia de condutores tresloucados e impacientes, alguns, até, mesmo desbocados que se pelavam por um lugarzinho mais à frente na fila formada a partir do semáforo seguinte. Grandes riscos e inconvenientes por causa de dois ou três metros eram conquistas, vitórias importantíssimas, já que a vida se media em tempo útil aproveitado até à exaustão.

O comedimento e a sensatez tinham passado a obsoletos. Eram coisas que até os antigos, por vezes, punham em causa... Já ninguém queria saber disso. Considerados entraves, quem ainda se arriscasse a tê-los em conta era, no mínimo, disfuncional e tonto. Ninguém tinha tempo para pensar diferente.

Não era por, na sua Vespa amarela, Maria querer avançar mais depressa que a utilizava. Nada disso! Era mais pela sensação de liberdade com que percorria as estreitas alas que ia avistando entre as filas de automóveis, cada vez mais imponentes, que invadiam a cidade diariamente.

Estava habituada a ouvir bocas, de um modo geral de um gosto duvidoso; mereciam-Ihe a importância que lhes costumava dar: um interior encolher de ombros - a reaç̧ão que se dispensa aos ditos pouco espirituosos.

Mas, daquela vez, fora diferente. Ao lado dela parara alguém e ela ouvira uma voz que a interrogava: "Dais-me a honra de vos dirigir a palavra?", perguntavam-Ihe com um sotaque arrastado.

Apanhada desprevenida, Maria levantara, instintivamente, a viseira do capacete enquanto olhava para a esquerda. E o que via deixava-a boquiaberta.

A característica figura facilmente identificável de D. Quixote, montada num pouco garboso cavalo conduzido com alguma insegurança, indagava de novo: "Permitis-me que vos dirija a palavra?"

Mas o que era aquilo? Maria não conseguia articular um som!

D. Quixote continuava: "Venho a seguir-vos desde que vos vi sair de casa. Apercebi-me de semelhanças extraordinárias com a minha Dulcineia e decidi atrever-me a uma aproximação. $O$ meu escudeiro, que pensa que eu não estou em mim, não quis acompanhar-me, portanto, não tenho quem abone em meu favor junto de vós, o que, pensando melhor, até é capaz de ser preferível. Já que não conheço aqui ninguém que interceda por mim, resolvi abordar-vos directamente."

Maria olhava o "Cavaleiro da Triste Figura" (de facto, até o achava bem digno) montado no mirrado Rocinante que não parecia muito satisfeito. 
D. Quixote continuava: "A minha Dulcineia não me sai do pensamento. Vejo-a em cada esquina, a cada passo. Quando me aproximo, porém, esvaise como se fosse uma miragem. Ainda bem que consegui chegar perto da vossa montada e de vós. Sabei que, embora me julguem alucinado e pouco merecedor de crédito, sei muito bem o que quero. Penso que este mundo se tornou numa espécie de selva, na qual os grandes ideais se perderam. Sei que a tarefa é árdua, mas a minha determinação em restaurá-los não conhece limites. Se tivesse a minha amada Dulcineia comigo seria, porém, menos difícil a investida! Paz, justiça e amor. Luto por isto. Parece assim tão estranho? Bem vejo que vos deixo sem palavras. Talvez não me tenha feito entender com clareza. Dizem que caio frequentemente nesse erro. Enfim, gostava de vos ouvir!"

Maria, simultaneamente crente e descrente no que presenciava, não sabia o que dizer. Também não sabia o que fazer. Começava, aliás, por não saber o que pensar! Que coisa deveras incrível! Ela mesma começava a duvidar do seu próprio juízo, mas a determinação do Cavaleiro era inabalável.

"No caminho para este lugar, fará algumas semanas, tive que enfrentar gigantes que me toldavam o percurso, isto para não falar dos exércitos que, entretanto, convergiram na minha direcção. Imaginai o esforço que me foi dado fazer para chegar até aqui!"

Maria não se atrevia a contrariar tal personagem. Lembrava-se muito bem de ter lido, em tempos, um poeta interessante, de seu nome Gedeão. Escrevera este que todos tinham a sua parte de razão, falando, até, de D. Quixote e Sancho Pança: "Vê moinhos? São moinhos. Vê gigantes? São gigantes." Era qualquer coisa deste género. "Pensando bem", reflectiu Maria, "todos têm os seus motivos para agir assim ou assado."

A luz verde do semáforo acendeu-se. Maria imediatamente começou a ouvir buzinadelas.

Do primeiro automobilista que a ultrapassou, ainda lhe chegou uma graçola: "Para zebra corres pouco...Estás a dormir?"

Quando olhou, de novo, para a esquerda, D. Quixote já lá não estava. No meio da selva, isso sim, continuavam todos! 
P.S.: Recomenda-se a leitura de "Impressão Digital", de António Gedeão. A bem dizer, partilha a minha gratidão, no que a esta divagação diz respeito, com Miguel de Cervantes. 

HISTÓRIAS DO DIA E DA NOITE 



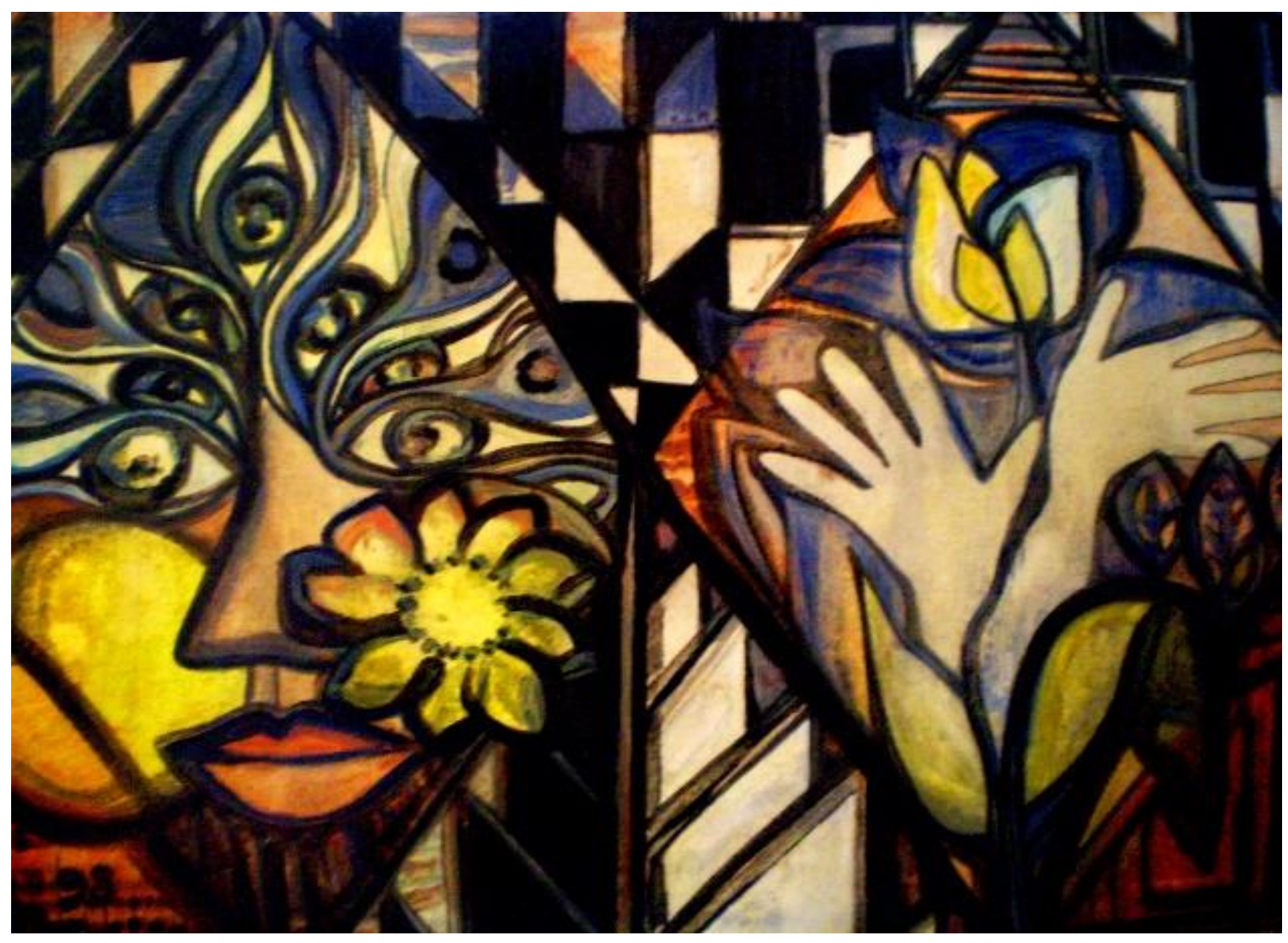

Óleo s/ tela 66 × 82 cm - 1998 

O sono tinha-se perdido e, com ele, também o sonho.

O sonho tinha cara de verdade, mas era mentira, porque quando Manuel acordou percebeu que continuava sozinho, estendido na relva do jardim, onde andara às voltas desde o cair da noite.

Se tivesse asas, o sonho não teria sido um sonho mentiroso. Manuel teria voado e teria acabado por encontrar a porta da Casa para onde ela tinha ido viver três anos antes.

Essa viagem misteriosa que ele gostaria de ter feito com ela, tê-los-ia levado em sorrisos e alegria, em cúmplice ternura, em lânguida doçura, a um lugar do qual não teriam querido voltar. Ela acreditava nisso e não se cansara de lho repetir nas últimas semanas. Manuel só tinha era vontade de ir com ela, porém, apenas lhe fora dado vislumbrar o prenúncio da viagem, carregando, agora, a triste e pesada recordação do momento da partida a que assistira como se estivesse do lado de fora de si próprio.

Nessa altura, teria preferido que tudo fosse mentira. O vazio que logo começara a instalar-se dentro dele, impedia-o de pensar e sentir ao mesmo tempo. Achava-se roubado, espoliado, ludibriado. Deixara-se enganar, deixara-se ultrapassar pela pressa da partida e essa "coisa" avassaladora tomara-o por inteiro.

Quando o momento chegou, ela não o levara consigo. O que Manuel viu foi o fundo dos céus nos olhos dela, enquanto se afastava. Portanto, ela tinha asas. A ele, faltavam-Ihe. Por isso ficara. Tudo, em redor, deixou, então, de existir.

Sentiu um arrepio percorrer-lhe o corpo. Poderia ter sido tão simples: ela tê-lo-ia levado, ele teria ido, sem hesitar. Mais tarde, apetecera-lhe fugir. Via aquela lua que a mulher apaixonada que ela fora nunca se cansara de olhar. Ele nunca chegara a saber que entre ambas existia um entendimento secreto. A distância não era impedimento. Todo o espaço era translúcido e elas cruzavam olhares serenos, à noite, quando se olhavam nos olhos.

Manuel não a quisera ver mais, àquela lua. $O$ ar patético, pungente com que então, intencionalmente, lhe virou as costas tinha sido esclarecedor. Um homem ferido, sangrando, um homem com a alma na mão sem saber o que fazer com ela. Uma alma tão pesada que tinha que ser pousada em qualquer lugar, entregue à sua sorte, porque Manuel preferia o vazio.

Seria? Tinha perdido todas as certezas, o tempo nada Ihe dizia; não tinha significado algum. Os dias não eram longos, nem as noites. Não! Longa era 
a ausência envolvida em saudade, a solidão que se instalara dentro dele, desde aquele dia.

Afinal, assim sendo, não era o vazio que estava lá. Havia algo que tinha começado a doer. Manuel tinha passado a conviver com a dor e começado, com ela, um diálogo que os mantinha presos; acabara por querer procurar a alma de chumbo que perdera algures.

Mas onde? Onde é que se reencontra uma alma a quem fizemos esconder-se de nós, uma alma que não quisemos por perto? Onde?

Primeiro é preciso quere-la próxima, mesmo que a aproximação prenuncie mais dor. Depois, há que saber encaixá-la de novo no lugar que foi o dela. Pode não se ajustar ao espaço vazio que outrora ocupou.

Se houver determinação, muita mesmo, porque o esforço tem que ser enorme, pode ser que ela queira, de novo, moldar-se para caber outra vez no seu espaço. Fá-lo-á vibrando, lutando, chorando sem lágrimas, gritando sem que se ouça. Será como que o anúncio de uma transfiguração que só acontecerá se valer a pena, se for desejada.

Manuel não estava muito seguro da sua coragem, mas tinha percebido que, quase sem querer, tinha começado a sentir a falta dessa outra dimensão do seu ser, a que lhe permitia vislumbrar o indefinido para além da bruma. Tinha uma estrada para percorrer, tinha sim, mas levá-lo-ia onde?

Estava cansado! Precisava de sentir paz! Paz sofrida, mas inadiável, paz em elaboração, mas profunda.

Manuel esfregou os olhos com força, acariciou a barba e passou repetidamente as mãos pelo cabelo indisciplinado. Levantou-se devagar e olhou em redor a exuberância de um jardim a acordar. Tudo aquilo era, também, memória dela e continuava vivo e belo, persistindo em oferecerse todas as manhãs.

Em algum lugar o coração dela continuava a bater. Batia, tinha de bater, e, porque era assim, Manuel escancarou as portas para que a alma entrasse, acedendo ao convite.

P.S. Com o Adagio de Albinoni gravado na alma, fui deixando correr a pena. 
ANTIGAMENTE, NA PRIMAVERA 



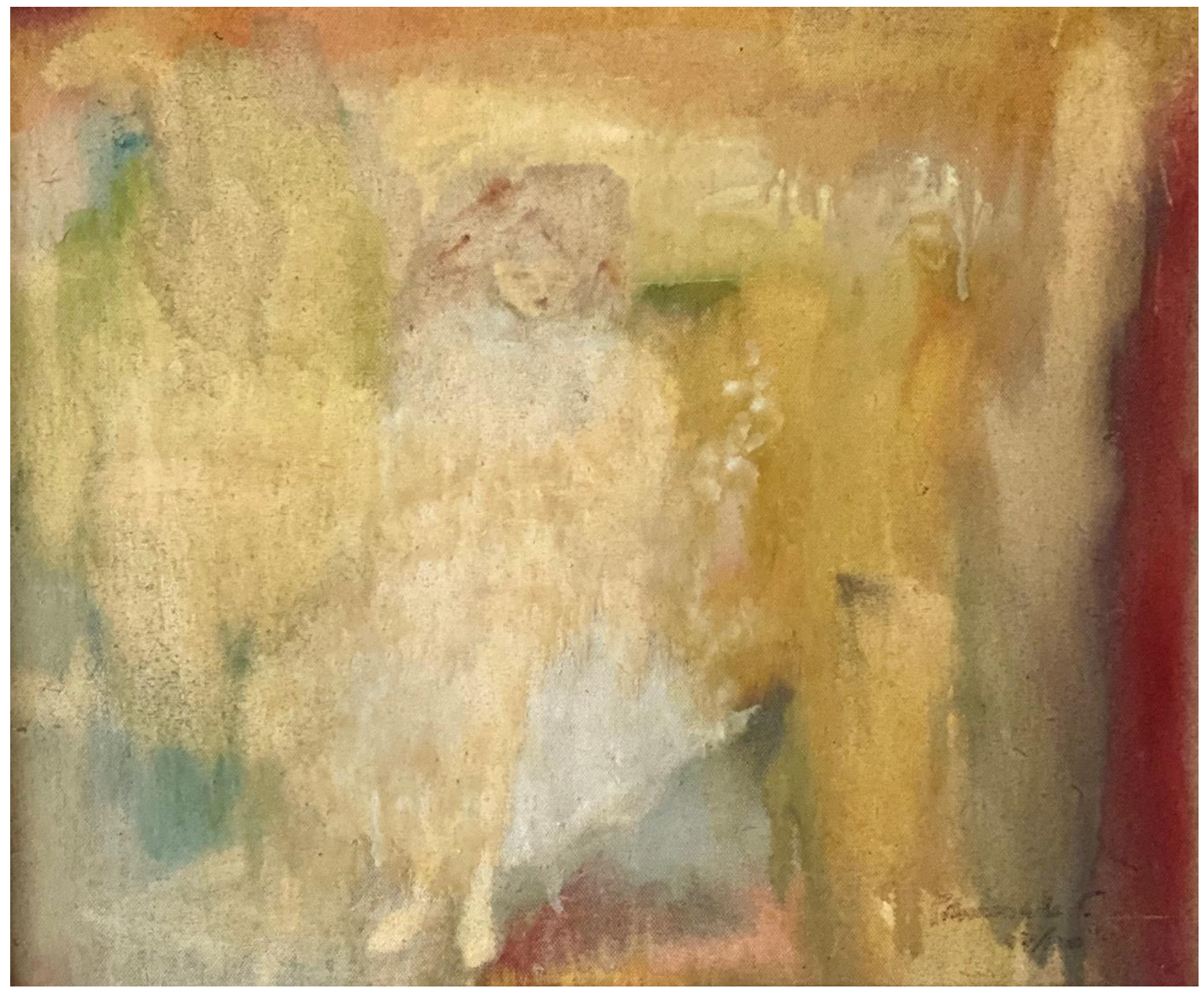

Óleo s/ tela 38 x 45 cm - 1989 

Sentiu primeiro um leve cheiro a perfume. Um perfume floral, fresco, a fazer lembrar o cristal; nada doce, quente ou pesado. Decididamente floral, como um soneto simples e feliz encontrado na gaveta de uma papeleira antiga, num dia de Primavera.

Na sua juventude, ela escrevia poemas que guardava aqui e ali ou deixava entre as páginas de um livro.

Queria recolher o sol e as flores amarelas que cobriam o chão em redor. Neles fazia rimar flor com valor e amor, sol com girassol e si bemol. Queria fazer perpetuar os murmúrios misteriosos que ouvia à sua volta, o tempo que mudava a cada minuto que passava, a calma e a agitação que o mundo em torno dela lhe trazia.

Trilhara caminhos, cruzara atalhos, percorrera estradas, nem sempre sabendo se chegaria onde queria. Alturas houvera em que nada fora fácil, momentos em que teria voltado atrás, talvez até desistido, se não fosse o facto de saber que as lágrimas também fazem bem à alma.

Quando as horas paravam no tempo, ela detinha-se, também, mas deixava que o pensamento se soltasse. Quase sempre tudo acabava num poema que começava na sombra e acabava na luz.

Se calhar, porque nunca quisera verdadeiramente fugir da vida; encaravaa ora chorando, ora rindo ou sorrindo, sempre que saía dela própria e se entregava ao ritmo do percurso desconhecido, por cumprir.

Quem é que, um dia, restituiria aos dias aquilo que ela ia escrevendo e deixando por onde passava? Uma filha, uma neta, um qualquer desconhecido?

Decididamente, pensou, a Primavera era amiga de revelações. ApeteceuIhe, naquele momento, segurar os raios de sol que espreitavam por entre as nuvens e deixar escrito, para que alguém soubesse que ela tinha descoberto que nenhum caminho tem retorno, que as distâncias podem não existir dentro das nossas cabeças, que o arco-íris tem as cores que quisermos ver nele, porque o rio de lágrimas que brotam de uma tristeza profunda acaba, inevitavelmente, por desaguar num oceano que, de revolto, pode transformar-se em bonançoso.

Era isto a Primavera. Um tempo de perfumes, muitos, de palavras novas, de esperanças, às vezes ténues, mas presentes. A Primavera trazia-lhe lembranças musicais. Notas soltas nas quais mergulhava num enleio de palavras que as traduziam, porque para ela era mais fácil.

Ah! Como tudo era mais fácil na sua juventude. Que saudade das ilusões que já não guardava; que saudade do tempo em que, inquieta, encarava cada nova experiência com avidez; que saudade da filosofia atenta, 
sempre interrogativa, abrindo-lhe mil portas ao mesmo tempo, simplesmente porque ainda não conhecia...ainda não sabia...

Mas, afinal, a Primavera regressava em cada ano, e, apesar dos anos que tanto the pareciam poucos, como pesados, voltava sempre. O sol, as flores, o mistério que pressentia nos murmúrios que ainda ouvia, de vez em quando, os ritmos oscilantes do mundo em torno de si, não podiam deixar de estar presentes na sua vida. Ela continuava ali, no meio deles.

Tinha havido uma altura, seguramente, em que o turbilhão dos seus pensamentos se tinha deixado substituir pela afirmação da caminhada. Mas, se ainda havia caminho a percorrer, porquê a saudade que magoava, porquê a melancolia?

Ali estava, de novo, a Primavera; ali estava, de novo, o tempo da sua juventude. Pegou na caneta e escreveu:

Sentiu primeiro um leve cheiro a perfume...

P.S. Ah! O encanto e a leveza de Mozart, no belíssimo trecho que tanto gosto de ouvir - a Fantasia em dó menor (K397). 
CAVALO NA PAISAGEM 



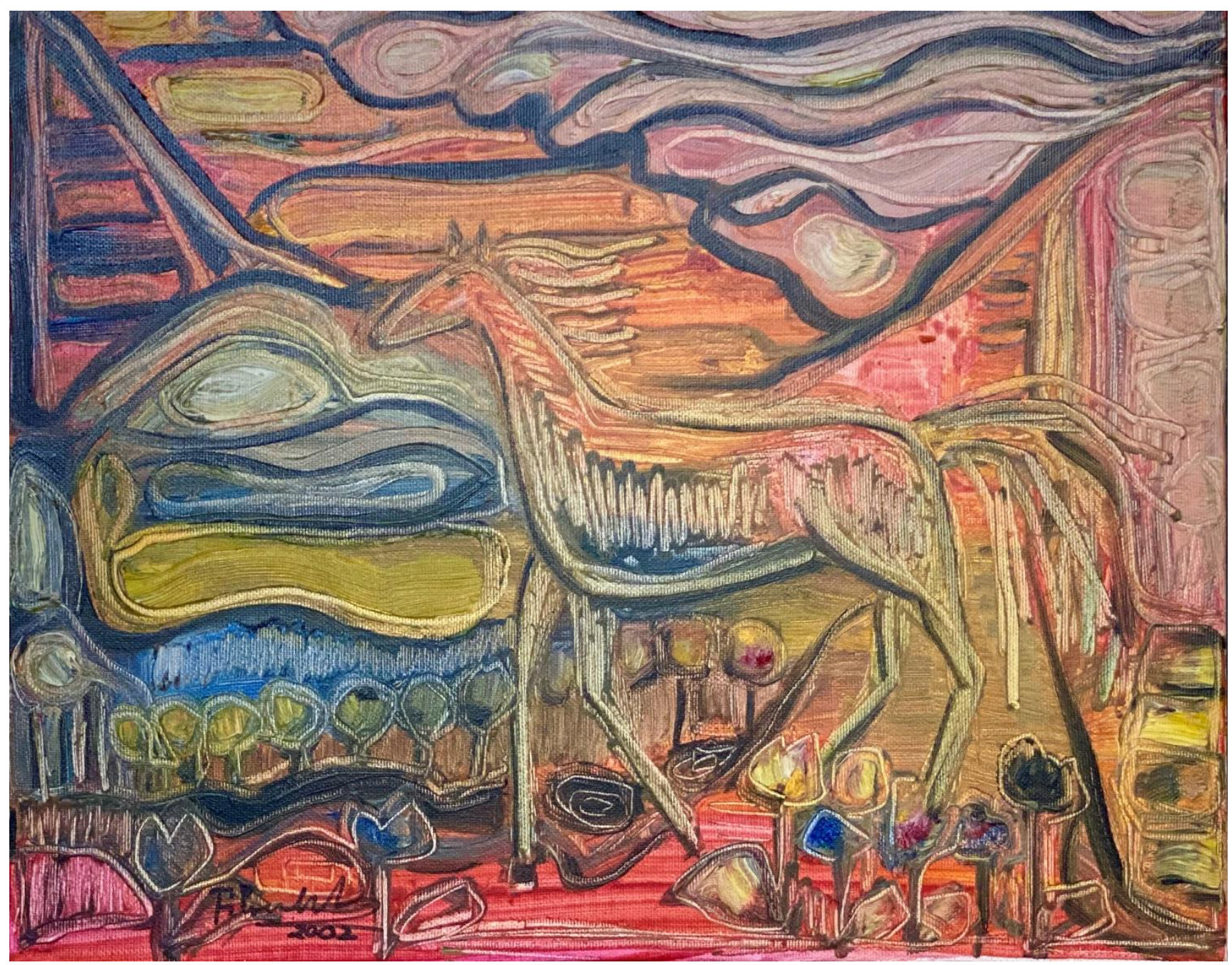

Óleo s/ tela 31 x 42 cm - 2002 

Corria o Ano da Graça de 1813. José Bonaparte estava na mó de baixo, em maré de azar.

Alguém Ihe tinha vindo dizer que teria de enfrentar o Duque de Wellington, lá para os lados de Vitória. Passava-se isto em Espanha, quase em cima do início do Verão; estava para acontecer o solstício de Junho.

Bonaparte, a quem já, em boa verdade, a coroa pesava em demasia, quis consultar o Além e saber que futuro lhe prediziam os entendidos na matéria, os tais que adivinhavam o que estava para acontecer, quando levantavam o dedo mindinho e, ao sabor do vento, conforme a sua inclinação, anunciavam júbilo ou desgraça.

Montou o seu belo cavalo e dirigiu-se à tenda do descendente do último druida gaulês.

Ora este, que de adivinho tinha tanto como de sensato, ergueu o seu dedito mágico e logo lhe disse que via as coisas difíceis para os franceses e que, inclusivamente, as arcas que o exército carregava com as jóias da coroa espanhola, não chegariam a abandonar o solo de origem. 0 panorama estava mesmo muito mau!

Mortos e feridos aos montes, baionetas e sabres e outras coisas à mistura, cabeças, como pedras, a rolar pelo chão, gritos e confusão generalizada, era isto, segundo o "vidente" o que estava prestes a acontecer.

"Ó diabo!", pensou Bonaparte. "Lá terá de ser, mas estou mortinho por ir embora. O pequenitates do meu irmão sempre foi ambicioso, mas, agora que a situação se complicou, devíamos era tratar de refrear esta mania das grandezas que nos corre nas veias. Melhor seria que regressássemos o mais pacatamente possível a casa e nos deixássemos de ideais imperialistas!" (Mal sabia ele de que forma lhe haveriam de gastar estas palavras nos séculos vindouros...)

O cavalo de José Bonaparte tinha ficado à entrada da tenda, obediente, aguardando o dono.

Ouviu, claro, o auspicioso discurso e pensou" Bonito! Há-de ser forte e feio! Até agora tenho escapado, mas não sou gato, nem terei sete vidas e, pelas minhas contas, considerando aquilo por que já passei, tenho andado a tentar a sorte há muito tempo. Isto não há-de durar sempre. Valha-me Santa Cavalina! E se eu me pusesse a andar daqui para fora? Naturalmente arranjavam logo quem me substituísse. Cavalos não faltam. Não me está a apetecer nada ser carne para canhão!"

Do pensamento à acção foi um ápice. Conseguindo libertar-se sem chamar a atenção, foi-se o cavalo afastando devagar, a passo, mais adiante a trote e, finalmente, quando lhe pareceu ser mais seguro, a galope. 
Galopou até não poder mais. Aí decidiu descansar.

Ao dar por si de novo, encontrava-se no meio de um bosque frondoso, pleno de cambiantes, num lugar que lhe soube bem e cheirava a perfume de rosas.

Lembrou-se, então, da égua que Julie, a mulher de Bonaparte, montava, quando a conhecera em Nápoles. A sua elegância nunca ele a tinha esquecido; pena era que Julie não tivesse querido viver com o marido em Espanha. Se o tivesse feito, a sua égua preferida tê-la-ia, sem dúvida, acompanhado. Os dois teriam, assim, convivido mais e, quem sabe, se não teriam, até, constituído família...

O cavalo de Bonaparte era mais ou menos tímido. Nunca se tinha afeiçoado muito ao dono que achava demasiado belicoso e amigo de tronos que só davam problemas: "Que vida cansativa e perigosa. E logo eu, que sou pacífico...Bem, pelo menos safei-me a tempo e horas. Isto de ser cavalo real tem muito que se Ihe diga! Só não percebo é como é que nunca deram conta! Não há dúvida: quem vê caras, não vê corações!"

Assim fomos encontrar o cavalo de Bonaparte nostálgico, mas em paz, longe da fúria devastadora do campo de batalha, tranquilo por ter, digamos, "desertado".

Não podemos afirmar que se estivesse "a marimbar" para a pátria, sua honra e glória. Não! De modo nenhum! Simplesmente prezava, acima de tudo, a sua vida de equino e entendia que poderia ser mais útil vivo do que morto. Era um cavalo pragmático.

Tratara, pois, de salvar a pele.

P.S. A Ludwig van Beethoven os meus veementes agradecimentos pela sua Op. 91. Foi ao som da Vitória de Wellington que se foi desenvolvendo esta história. 
A ENIGMÁTICA ILHA DA PÁSCOA 



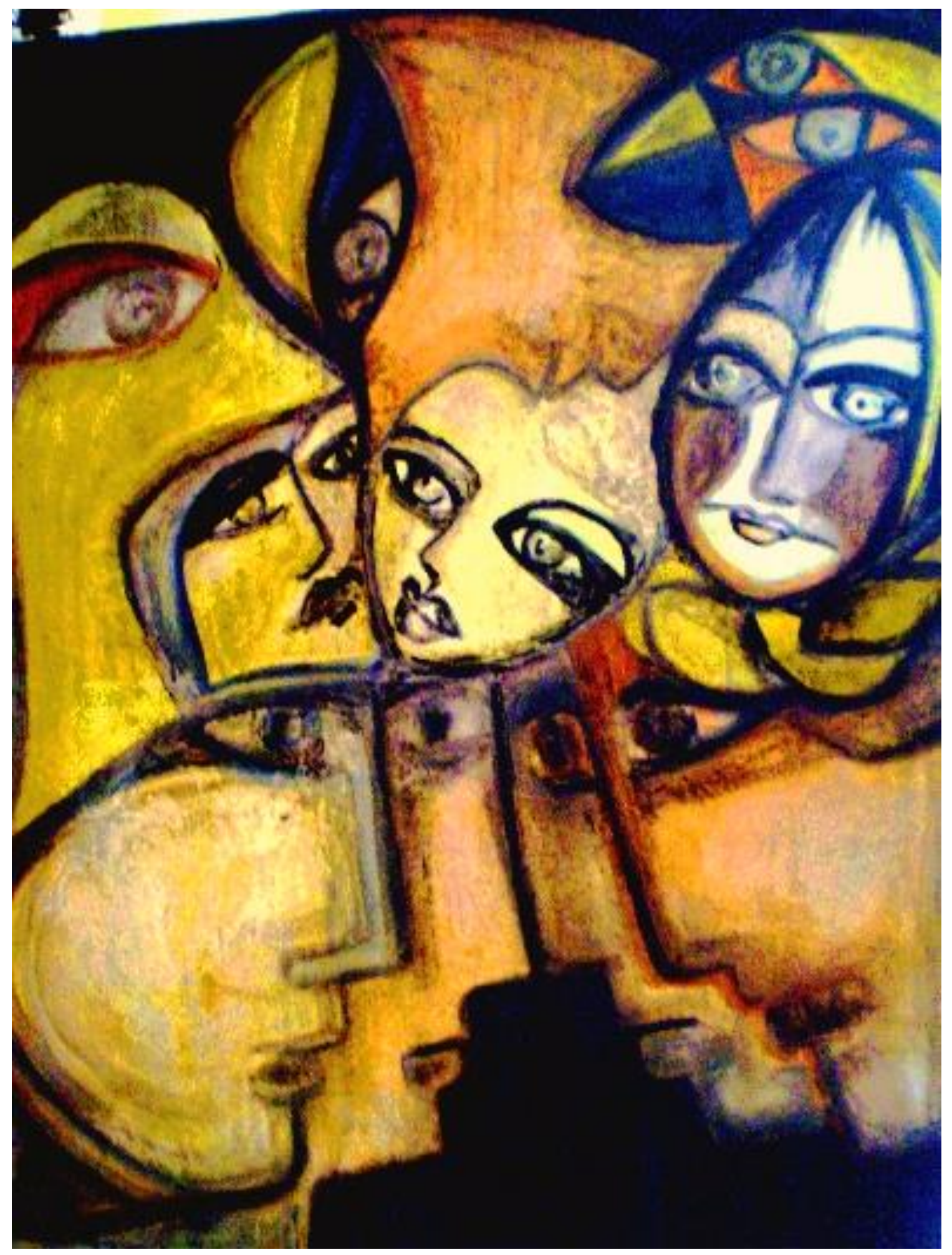

Técnica mista 92 x 73 cm - 1999 

Mrs. Robinson tinha posto o marido fora de casa. Estava farta. Comportava-se como um selvagem. Pois que o fosse, mas longe dela. Numa ilha distante, se possível.

Aconteceu isto numa sexta-feira memorável, na véspera da partida para umas férias numa famosa ilha de "enorminhos", algures na Polinésia, bem lá para o Baixo Pacífico.

Com as passagens na mão e Mr. Robinson despachado, Mrs. Robinson ficou sem saber bem o que fazer. A simpatia da família, dos amigos e dos vizinhos ia toda para ela. Apoiá-la-iam, seguramente, quando tivessem conhecimento do que se passara. Não convinha era que as crianças se apercebessem, mas, como estavam num campo de férias, o problema não se punha imediatamente. Mrs. Robinson confiava nisso. Era uma pessoa positiva!

No momento, tinha era que se concentrar na história das férias. la? Não ia? O que faria?

Mr. Robinson acabara de lhe ligar. Queria a sua passagem. Tentaria mudar os voos, mas estava determinado: "Ilha, aí vou eu!", foi o primeiro pensamento que the ocorreu quando, à hora do almoço, lembrando-se de que era suposto comer qualquer coisa (a "ordem de despejo" tinha sido acatada em jejum) começou a organizar as ideias, enquanto esperava pela sopa.

Voltemos, pois, a Mrs. Robinson que tinha acabado por decidir aproveitar as tais férias há tanto tempo planeadas por ela mesma. Sim, porque Mr. Robinson era mais do género de passar horas a fio enterrado no sofá fixando Joe DiMaggio que passava de bestial a besta em segundos, coisa que está sempre a acontecer aos heróis.

Em meados do século passado, a vida corria mais devagar; o próprio DiMaggio corria mais depressa. Todavia, por mais lento que fosse o ritmo, havia sempre alturas em que era necessário agir rapidamente.

Mr. e Mrs. Robinson tinham, então, decidido partir, embora em voos diferentes, rumo à misteriosa llha da Páscoa. Nos aeroportos não era provável que se cruzassem. A viagem seria longa, com transbordos em três escalas. De Santiago do Chile até à ilha é que só havia um voo por semana. Era aí que, presumivelmente, dariam de caras um com o outro. Paciência!

Mrs. Robinson, cheia de malas (era uma pessoa previdente e não confiava nada nos meteorologistas) desembarcou, pois, em Santiago. $\mathrm{O}$ avião para a ilha partiria dali no dia seguinte, ao fim da tarde. 
Bem instalada, por uma noite, não foi, porém, capaz de dormir, porque se sentia tensa e, no fim de contas, preocupada. Afinal, os acontecimentos das últimas 48 horas tinham-se sucedido de forma quase alucinante e a quinzena que se avizinhava traria "peripécias" bizarras, com certeza...

Enfim, ali estava ela. Mr. Robinson, se não chegara ainda, chegaria no dia seguinte. Mrs. Robinson suspirou profundamente, resignada à sua sorte e à espera do avião que devia levantar voo daí a umas horas.

Chegada, mais uma vez, ao aeroporto e cumpridas as necessárias formalidades, sentou-se, tendo antes discretamente "inspeccionado" a sala. Nem sinais de Mr. Robinson. "Atrasado, como sempre", pensou ela. "Vá lá! Desta vez, ao menos eu já cá estou!"

A partida foi anunciada, o nome de Mr. Robinson chamado mais do que uma vez, mas sem sucesso. "Não tem mesmo emenda!", discorreu Mrs. Robinson, enquanto se ia instalando num acanhado lugar à janela. "Sempre imaginei que chegasse em cima da hora, mas nem isso. Melhor! Antes assim! Estou com pouca vontade de o encarar."

Mas, afinal, por onde andava Mr. Robinson? Isso, mais do que qualquer um, gostaria ele de saber.

O avião que o transportava para Santiago nessa manhã, quase madrugada, tinha-se despenhado, praticamente sem aviso prévio, em terra desconhecida.

Quando se apercebeu de que algo de muito grave estava a acontecer, Mr. Robinson lia a última entrevista de DiMaggio. Só teve tempo de pousar o jornal. No minuto seguinte, foi a vez de o avião "pousar" com o maior dos estrondos e de forma absolutamente desastrosa entre troncos e ramagem.

De facto, fora um desastre, um terrível acidente, uma queda brutal. Mr. Robinson gemendo em todos os tons (fora sempre muito gemebundo) olhou à sua volta, quando acordou.

Para além do caos total e de ruídos que não identificava, não ouvia voz humana, nem nada que se parecesse. Ao fim de minuciosa busca, concluiu que tinha sido o único sobrevivente e que, milagre dos milagres, tinha saído incólume, sem mesmo uma beliscadura, do desastre.

"Mas, afinal, onde estou?", interrogava-se, tentando abafar o receio, o medo, o pavor, o terror que lhe iam chegando em crescendo. "Preciso de sair daqui e já!"

Enquanto isto acontecia algures, Mrs. Robinson voava rumo à llha da Páscoa. Os tais "enorminhos" de pedra, principal atracção da ilha, sempre 
a haviam seduzido. Estava curiosa. Tinha lido algo sobre eles e a sombra de mistério que pairava sobre os ditos fenómenos excitava-a.

Não chovia quando aterrou. Mrs. Robinson foi conduzida ao hotel, onde logo pediu a chave da suite que tinha reservado. Tendo-se refrescado, estendeu-se na larga cama e acabou por adormecer.

Curiosamente, Mr. Robinson fazia o mesmo naquele momento. Ainda não sabia que durante 28 anos adormeceria sozinho e que, entregue a si próprio, feito um outro homem, vivendo uma experiência única, Ihe seria dado encontrar outro ser humano, um dia. Nesse dia, "contrataria" para o servir (ou acompanhar...) um estranho indígena ao qual passaria a chamar Sexta-Feira porque disso nunca ele se tinha esquecido: a sua vida tinha mudado em absoluto numa célebre sexta-feira em que Mrs. Robinson o tinha despachado de casa para fora.

Mas, se Mr. Robinson não tinha regressado, Mrs. Robinson também não. Porquê? Que estranha sorte tinha sido a dela?

Vejamos: contentinha por se ter visto livre do marido e o ter posto no seu lugar, que é como quem diz, longe dela, e, mais satisfeita ainda por, ao fim de uma semana, não lhe ter posto os olhos em cima, quis passar a última noite tranquila, já que o tal voo semanal deveria acontecer no dia seguinte e Mr. Robinson desembarcaria, como ela previa. "Lá se me vai o sossego..."

Foi, então, Mrs. Robinson carpir mágoas e queixas para junto dos Moais, literalmente aos ais, embora apenas audíveis, como manda o decoro. la falando sozinha, distraída, alheada até das próprias estátuas, consumida por aquela raivazinha escusada que ia alimentando.

Foi, assim, entre lamentos que acabou por sentir uma força estranhamente poderosa que a atraía como um íman e praticamente a arrastava, sugando-a para um determinado ponto.

Mrs. Robinson sabia que havia quem chamasse àquela ilha o Umbigo do Mundo. Ora, o que the aconteceu estava relacionado com isso. $O$ umbigo, o misterioso umbigo abriu-se e acabou por engoli-la, sem apelo nem agravo.

Os Robinson não voltaram, na verdade, a encontrar-se.

Sabemos, porém, de fonte segura que está previsto um "acerto de contas" um dia, quando, noutras circunstâncias, voltarem a ver-se. Talvez caiam nos braços um do outro!

Talvez... 
P.S. Robert Louis Stevenson, Daniel Defoe, Simon \& Garfunkel: obrigada pela "inspiração"! 
MENINAS A BRINCAR NO JARDIM 



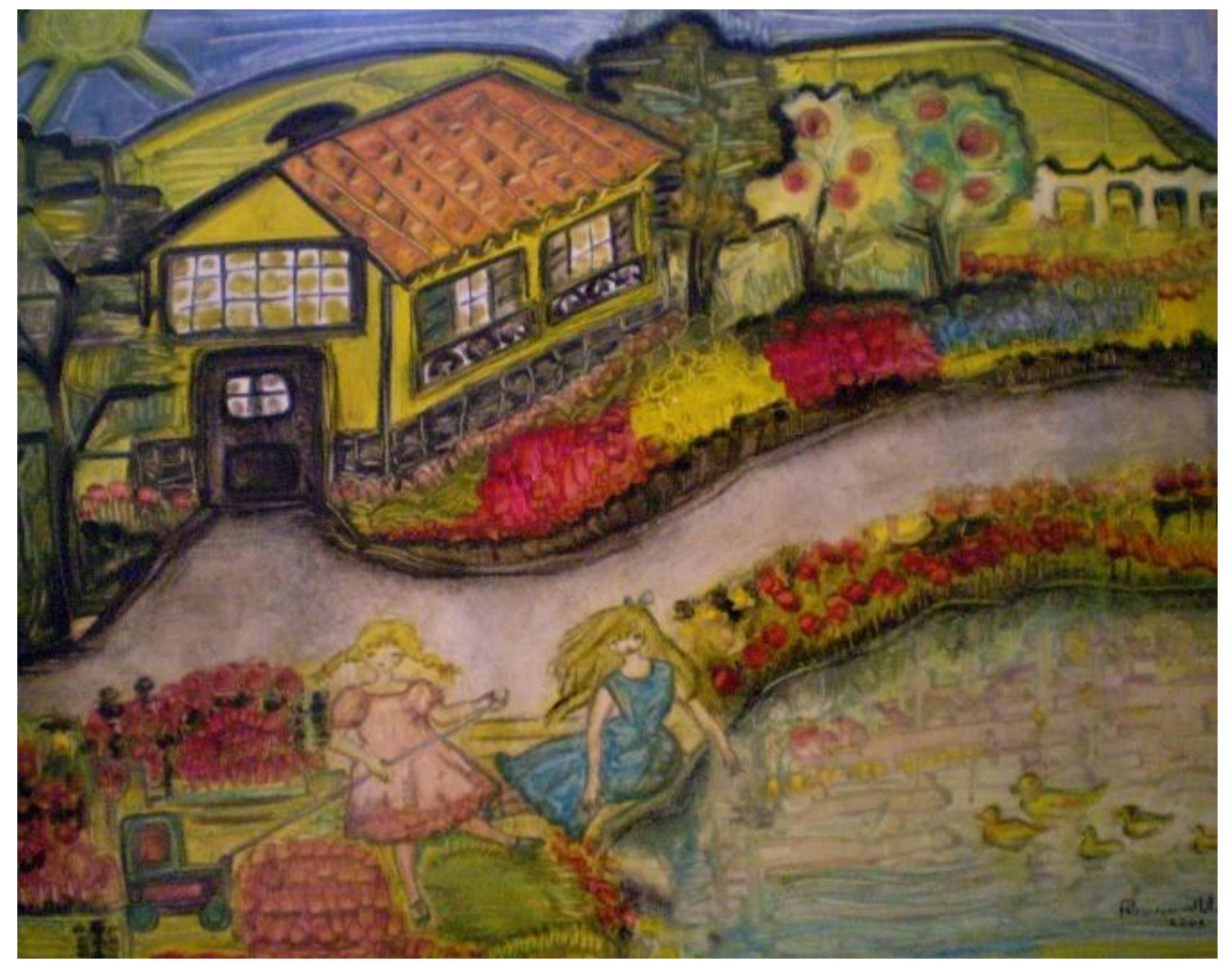

Acrílico s/ tela 50 x $60 \mathrm{~cm}-2001$ 

Maria Ana pensava. "Pensar cansa, credo! O que será que acontece dentro da cabeça quando pensamos? São tudo células, têm nomes e as minhas não param quietas! Sinto-as a mexer o tempo todo!"

$\mathrm{Na}$ verdade, meia hora antes, alguns neurónios tinham ido buscar um escadote bem alto para conseguirem chegar a um calhamaço enorme que estava numa prateleira. Como era pesadíssimo, tinha sido complicado trazê-lo para baixo, mas tinham-no conseguido. Tinham arrastado uma mesa na qual o tinham pousado e, abrindo-o, entre exclamações de espanto, leram a página de rosto, onde se anunciavam histórias tão convidativas que vividas à luz do dia ou enquanto Maria Ana dormia, seriam, com certeza, deliciosas.

A primeira era a história da princesa Maria Ana que um dia se vira com um reino nos braços e dez milhões de súbditos resmungões. Um dos neurónios maiores estava nervosíssimo. Tinha recebido uma quantidade de sinapses ao mesmo tempo. Estava quase em estado de choque. Era demais! Já tinha ouvido falar de outras princesas, mas do reino da princesa Maria Ana descrito assim com requintes de pormenor que logo o faziam evocar outra história sua bem conhecida, isso era novo!

Ora então, três neurónios debruçavam-se sobre o livro e tentavam segurar a folha que parecia agitada. Maria Ana estava, sem dar conta, exactamente no trajecto de uma valente corrente de ar que lhe entrava pelo ouvido esquerdo e passava direitinha sobre a grande mesa na qual se encontrava o livro. Aliás, a força que os axónios tinham que fazer era tanta que as caudas abanavam sem parar, de nervoso miudinho. Os neurotransmissores, habituados à mediação, bufavam por todos os lados e tinham até dificuldade em contactar os dendritos, tão agitados e excitados estavam!

Mas, realmente, exageravam. Maria Ana estava a pensar no que encontrara, dias antes, no sítio onde se encontra quase tudo o que é interessante: uma pequena caixa em madeira um tanto ou quanto carcomida, pousada sobre uma secretária antiga, no sótão de casa da bisavó.

Sentiu-lhe a leveza ao pegar nela. Quando a abriu, tarefa não muito fácil, encontrou lá dentro um papel amarelecido pelo tempo, no qual alguém escrevera o que parecia ser uma mensagem: "Vive! Vive dia e noite, vive de olhos abertos ou fechados, mas vive! Agarra o momento! Cada momento da vida é importante". Embora Ihe parecesse familiar, a ideia não deixou de causar impacto nela. 
O maior desgosto de Maria Ana era não ter uma irmã mais nova. Mais nova porque as irmãs mais velhas têm quase sempre uma tendenciazinha para mandar e ela não estava para isso.

Por ser única, a Maria Ana da história tinha herdado um reino complicado para governar e manter direitinho, o que lhe desagradava sobremaneira, pois não tinha sido fadada para tratar de coisas demasiado sérias, assim tão nova.

O mais curioso de tudo isto é que ambas haviam encontrado a mesma solução para o problema: imaginaram uma irmã mais nova, companheira constante com quem se sentiam completamente à vontade. Ana Maria era o nome de uma e de outra. Nova coincidência? O importante era que rapidamente se tinham materializado aos olhos de ambas e tecido entre si uma cumplicidade que tinha vindo a crescer.

Era o Reino-do-Faz-de-Conta? Paciência! Era bem mais agradável ter com quem partilhar o dia-a-dia.

A princesa Maria Ana era uma sonhadora. Gostava de correr sem rumo e de sentir o vento leve a bater-Ihe de frente no rosto. Saía com Ana Maria do palácio, sem que ninguém desse conta, parando só quando se sentiam cansadas. Aí, deitavam-se sobre a caruma dos pinheiros, imaginando o mundo de pernas para o ar e todo ao contrário. Era divertido, às vezes embaraçoso, mas, decididamente, um gozo. Ser muito certinho e ter os pés sempre assentes na terra era enfadonho, sobretudo quando os conselheiros do reino insistiam tanto nisso.

Maria Ana era, em parte, semelhante à princesa da história, mas, acima de tudo, gostava de brincar, aproveitando o facto de estar quase a ultrapassar a idade em que os adultos acham que isso ainda é normal. Atravessava o caminho que, só por acaso não era uma estrada de tijolos amarelos, e, com Ana Maria, inventava brincadeiras simples, entretendose ambas horas a fio.

A solidão só voltava quando, indecentemente, uma e outra eram chamadas à realidade: Maria Ana, a princesa, porque o ministro (com muitas pastas) Ihe pedia que assinasse um novo decreto que deveria ser promulgado. A outra Maria Ana, porque a mãe a chamava para vir estudar. Ah! Essa coisa dos testes, dos trabalhos, dos manuais quase sempre sensaborões era um aborrecimento constante. Aprendia muito mais fora deles... 
Mas as quatro tinham apostado em viver entre os dois mundos. $\mathrm{Na}$ verdade, como aquelas pessoas sábias que vão aprendendo a tornar os dias mais curtos, elas já tinham percebido que há pequenos truques para fazer a vida menos pesada.

O mais fácil de todos era o fazer-de-conta, imaginando um mundo que não existe. Ou será que existe?

P.S. Obrigada, Lewis Carroll, por ter querido permanecer na minha memória! 

FLORES NUMA CHÁVENA DE CHÁ 



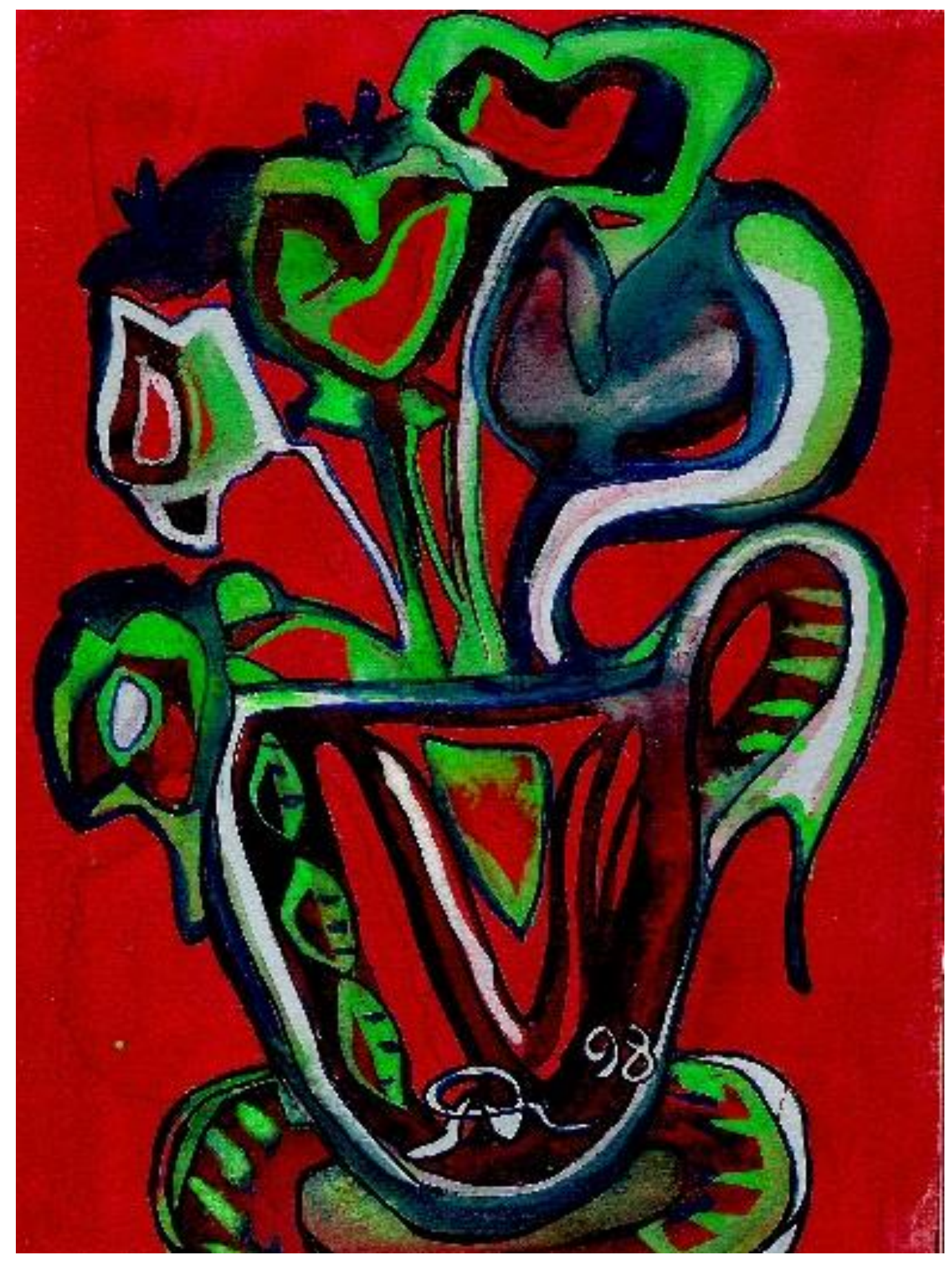

Aguarela s/ papel $21 \times 14,8 \mathrm{~cm}-1988$ 

Zé Maria tinha tido um dia horrível.

De manhã não ouvira o despertador, esse objecto (in)útil. Arranjara-se à pressa, coisa que detestava. Quando saíra, para tomar o pequeno almoço, o café em frente estava cheio de gente. Claro! Era mais tarde! Viu que ali não se safava. Para tirar o carro da garagem fora um desatino. $O$ espaço entre as colunas tinha diminuído durante a noite.

Quando chegou ao banco, a reunião já tinha começado. Todos olharam para ele como se olha para um réu num julgamento. A certa altura, ouviram-se os Queen: "We are the champions...". Era o toque do telemóvel dele. Esquecera-se de lhe tirar o som. Todos voltaram a olhar para ele, desta vez como se olha para um condenado. Para campeão, ia bem lançado, sem dúvida.

À hora do almoço, com os minutinhos contados, saíra para se encontrar com a namorada, que não aparecera. Esperara e fartara-se de esperar. Quando pegou no telemóvel, para Ihe ligar, reparou que o tinha desligado, com a atrapalhação, durante a reunião. Ligou-o e logo viu a mensagem dela: "Desculpa. Estou presa numa reunião. Não esperes por mim. Beijos. Até logo." Sim senhor! Já não ia ter tempo para almoçar. Comeu uma sopa à pressa.

A tarde fora um prolongamento da manhã, mas mais requintado. A secretária tinha sido chamada para ir buscar o filho doente ao infantário. Sendo o braço direito de Zé Maria, fazia-lhe uma falta tremenda e logo naquele dia, sexta feira e fim do mês. Se havia ocasião em que precisava de dois braços direitos era aquela. Foi tentando resolver as coisas com o seu, mas não parecia haver grande conexão entre este e a sua cabeça.

$\mathrm{O}$ pc persistia em dizer-lhe, sem rodeios nem cerimónia "File not found".

"Mas onde é que está o raio do dossier do Jardim Zoológico? Só a mim, também, é que entregam coisas destas! Macacos me mordam e aos financiamentos!"

No gabinete ao lado, ouvia vozes exaltadas. "Bonito! Alta tensão! Será que há perigo de morte? E se chega aqui?"

Saiu, discretamente, em direç̧ão à máquina de café, ao fundo do corredor. Avariada, informava uma folha de papel, colada às três pancadas.

Apetecia-Ihe partir qualquer coisa. Só por acaso não Ihe apetecia partir a cabeça. Aliás, nem valia a pena: sentia-a prestes a explodir!

Olhou para o relógio. Eram quase cinco horas.

Sentado à secretária, acabou, com mais calma, por encontrar o que pretendia. "Aleluia! Nem tudo está perdido. Vou é ter de ficar aqui até às 
tantas! Enfim, amanhã é sábado!" Imprimiu umas folhas e preparava-se para imprimir outras tantas, quando the irromperam pelo gabinete dentro: "Ó pá, ameaça de bomba! O edifício vai ser evacuado. Despachate!" "Era mesmo isto que me faltava", pensou Zé Maria.

Desceu 21 andares pelas escadas, rogando, baixinho, pragas a tudo e a todos. Quando saiu, deu conta de que chovia como no Dilúvio. Atravessou a larga avenida e ficou encolhido debaixo do toldo da ervanária situada em frente ao banco.

Distraidamente, olhou para a montra. Chás, chás e mais chás. "Por acaso, até me sabia bem um chá quente." Entrou. "Posso aconselhá-lo?", indagou, simpática, uma rapariga de olhos claros e cabelo curto. "Qualquer coisa para aliviar o stress, ou então um veneno eficaz!", respondeu de chofre. A rapariga sorriu, meteu a embalagem que escolheu dentro de um pequeno saco de papel e deu-lhe o troco.

Já cá fora, Zé Maria foi informado de que já ninguém voltaria ao banco nesse dia.

Meteu-se no carro e foi para casa. Ao chegar, não conseguiu encontrar o comando da porta da garagem. Na verdade, estava onde sempre estivera. A cabeça de Zé Maria é que não.

Estacionou longe. Não escaparia a outra valentíssima molha, estava-se mesmo a ver!

Quando, finalmente, entrou em casa, a única coisa que lhe apetecia era tomar um bom duche e enterrar-se bem fundo no seu maple favorito.

Feito isto, lembrou-se do chá. Levantou-se, com algum esforço, e foi pôr a água a ferver. Entretanto, voltou à sala, onde tinha, descuidadamente, deixado ficar o saquinho da ervanária. Levou o pacote para a cozinha e preparou o chá.

Enquanto se virava para o outro lado e pegava no açucareiro, nas suas costas acontecia magia!

Da chávena brotavam flores; flores como ele nunca tinha visto, e uma voz jovial perguntava: "Foi você que pediu uma chávena de boa disposição?"

P.S. Quem é que se lembra de "A Day in the Life", de Lennon e McCartney? 
A RAPARIGA DA LIBELINHA 



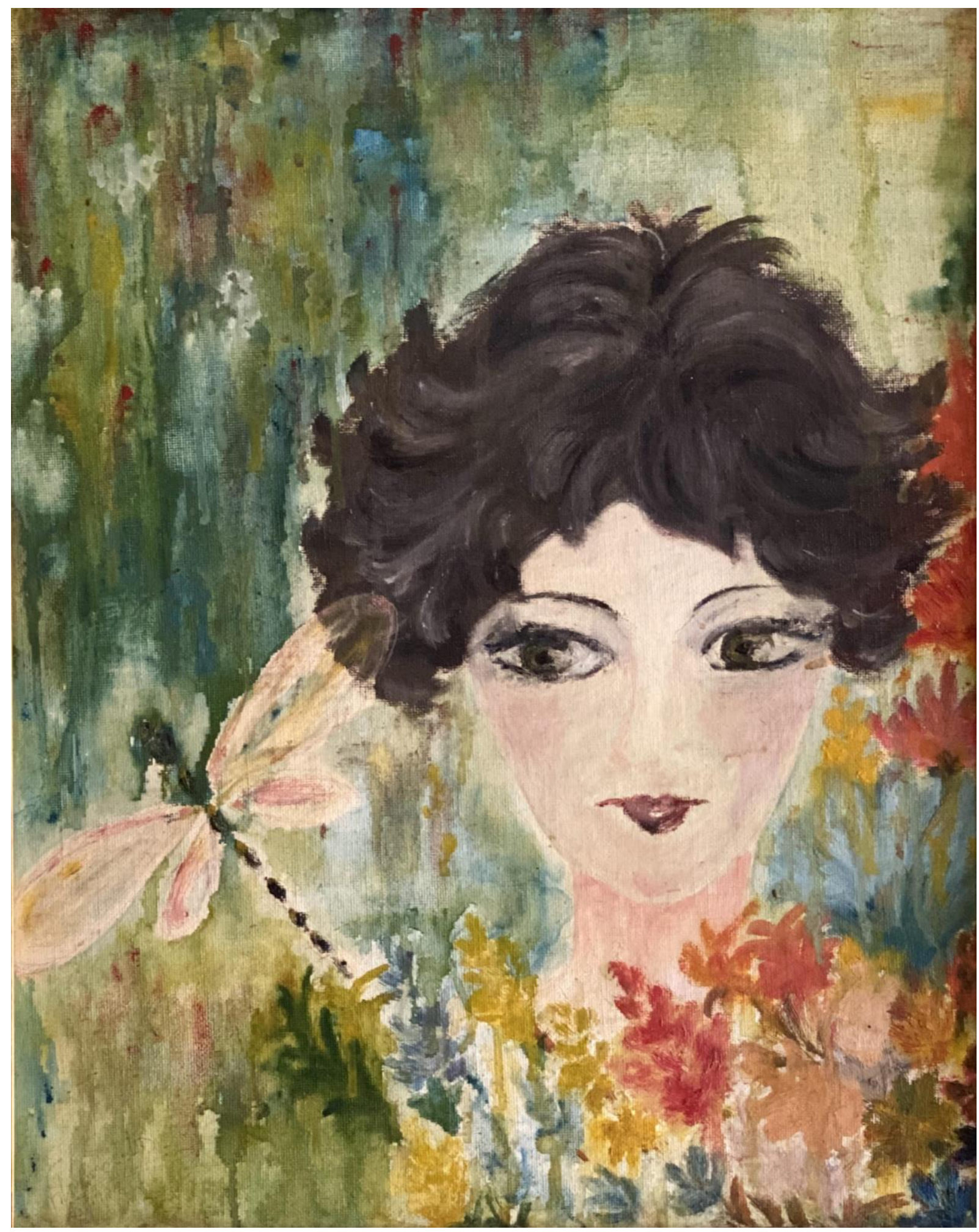

Óleo s/ tela 40 x 33 cm - 1989 

Madalena conhecia a Mãe como mais ninguém conhecia. Tinha estado lá dentro, perto do coração e dos pulmões. Tinha sentido o que ela sentia, respirado com ela ao mesmo tempo. Quando se espreguiçava e a Mãe Ihe pedia, de mansinho, para ter cuidado, ela tentava encolher-se, apesar de o espaço em que vivia ser cada vez mais pequeno.

Nos dois últimos meses, resolvera dar uma volta à vida: ficara de cabeça para baixo. Por acaso, assim, até achava que conseguia pensar melhor, embora o pensamento estivesse quase sempre concentrado na grande questão: "Como seria o mundo lá fora?". Sim, chegaria o dia em que sairia dali para ir fazer o reconhecimento do terreno.

Convinha que fosse um lugar pacífico, alegre, simpático, terno, colorido, um mundo onde se sentisse pelo menos tão bem como se sentia dentro da barriga da Mãe.

E as pessoas? Seriam queridas como a Mãe era? Gostariam de música e de flores como a Mãe gostava? E de chocolatinhos? Mmmmm...tão bons!

Nas casas das outras pessoas falar-se-ia como se se cantasse num tom doce? E elas preocupar-se-iam umas com as outras, querendo sempre saber se tudo estava bem?

E o Pai? Iria continuar a falar no plural, quando se dirigia à Mãe, e a fazerIhes festinhas à noite, antes de adormecerem?

Tanta pergunta! Tanta, tanta...

Madalena não tardaria a saber. Pelo menos, estava convencida disso.

Tinha razão. Acabou por chegar o dia das respostas. Não começou, de todo, como ela imaginara. Demorou tanto a decidir-se que, quando finalmente veio ao mundo, o dia já era noite.

De sol, música, flores, paz e sossego nem vestígios. Das duas, uma: ou nascera no sítio errado, ou não era, decididamente, aquela a melhor hora para obter respostas.

Esperou. No dia seguinte, logo de manhã cedo, rompeu o sol. A primeira coisa que Madalena sentiu foi o calorzinho do regaço da Mãe e a mão do Pai que Ihe acariciava a cabeça. Parecia que havia flores, mas não conseguia distingui-las bem. Também cheirava a chocolate. Devia ser por haver, algures, uma caixa aberta. Mas, admirava-se Madalena, faltava a música, e isso era uma falha grave. Então? Essa tal "alma do mundo" de que a Mãe tanto gostava? Esses sons harmoniosos cuja falta se fazia já sentir?

Tudo isto passava pela cabeça de Madalena, nesse belo dia de Maio.

Para tudo isto foi encontrando respostas. Cedo, porém, percebeu que as questões que primeiro lhe haviam surgido, por mais importantes que 
fossem, não tinham a dimensão avassaladora que outras e outras foram assumindo na sua vida.

Madalena foi crescendo. As perguntas foram-se multiplicando mas, não raro, entender as respostas era mesmo muito, muito complicado!

Valia-lhe, quase sempre a música. Ah! O sentimento de plenitude que a harmonia dos sons Ihe transmitia era incomensurável. Viver sem música devia ser impossível!

Madalena já tinha compreendido que o mundo não era um mar de rosas. Contudo, aprendera a ouvir o canto da libelinha cor-de-rosa que costumava fazer-lhe companhia, quando passeava no jardim.

A libelinha não era presumida. Era, até, um pouco ingénua. De longe aparentada com o Grilo Falante amigo de Pinóquio, fazia-se ouvir com tal naturalidade, que Madalena acabou por perceber a sua linguagem.

A libelinha cantava a alegria, enquanto batia as suas asas transparentes. Mas, afinal, o que ia ela dizendo a Madalena?

Repetia-Ihe, sem se cansar, que a Vida é um dom e que tal não deve nunca ser esquecido.

O resto? $O$ resto era quase tudo, ou quase nada, pois se até as rosas têm espinhos... Importante é confiar, mesmo que as respostas para as nossas interrogações não existam.

P.S.: A Manuel António Pina mil vezes obrigada, por me ter emprestado a sua Ana.

Mais grata, ainda, fico a Johann Sebastian Bach pela eterna beleza da sua música, neste caso concreto pela Cantata BWV 147 "Herz und Mund und Tat und Leben". 


\section{POSFÁCIO À FLOR DA PELE}

Entre a paleta e a pena, a pele. A flor da pele, o pelo. Essa réstia de animal, entre o que já não somos e o que ainda somos. Também aqui são reveladoras as etimologias, as histórias das palavras. Já nos textos medievais, "as penas" são pequenos aglomerados de pelos: há armazéns de penas que mais não são que entrepostos de peles. Dos pelos se fazem os pincéis, com que podemos pintar e escrever, ainda que depois eles se tornem as nossas canetas de tinta permanente, ou as nossas canetas nanquins, que ainda usamos para desenhar: sempre a pena é essa forma de passar de um texto para outro texto, de um suporte da imagem para outro suporte de imagem. "Pincel", em italiano se diz ainda hoje "penello", pequena pena. Da mesma forma que as nossas "pens" de USB retomam a ideia do instrumento de escrita ou de pintura. E no entanto, pincéis, penas e pens são continentes que, por metonímica, se transformam naquilo que transportam, os conteúdos.

1.Entre a forma e o conteúdo há uma prática mimética que excita a memória e dá razão a Crátilo. Muitas vezes as letras são desenhos e os desenhos são letras. Sempre houve muitas maneiras de interpretar o preceito de Horácio "ut pictura poesis", de uma poesia como a pintura. Dizia Simónides de Cós, um dos primeiros filósofos que exemplificou o poder da memória, que a poesia é pintura sonora, e a pintura uma poesia muda. E assim as guardamos ambas na memória, porque a memória gosta de palavras que possa associar a imagens e imagens que possa associar a palavras. Este livro de Filomena Vasconcelos e Isabel Pereira Leite é um elogio dessa memória fácil, à flor da pele.

2.É à flor da pele que desenhamos e escrevemos quando queremos ser felizes. Como se a escrita ou a imagem fossem uma forma depurada de atingir a nossa superfície exterior, ainda que a raiz irrompa de uma matéria viva e musculada a que chamamos vida. A verdadeira cultura pressupõe sempre essa abertura para o outro, esse rasgar da carne de dentro para fora, que revelará talvez a nossa forma de respirar, de não morrermos por excesso de eu. Assim é este livro. Uma forma de encontro que se diz provável. A probabilidade dos encontros exige precisamente, de quem pinta ou de quem escreve, uma vontade de diálogo, um profundo interesse por um conhecimento a dois, baseado na diferença. Um diá-logo. Neste 
livro, o ponto de partida é o quadro: como se de uma exposição se tratasse, os nomes dos quadros são os nomes das personagens dos contos: a sereia, os olhares na palma da mão, a noiva, os sete rostos, o jardim encantado, a cidade selvagem, as histórias do dia e da noite, antigamente na primavera, o cavalo na paisagem, a enigmática llha da Páscoa, as meninas a brincar no jardim, as flores numa chávena de chá, a rapariga da libelinha...

3.É à flor da pele que nos lemos, duas faces da criação. A oposição do masculino e do feminino, entre o pelo e a pele, é a mesma que existe entre o lago e a lagoa: como se a língua portuguesa teimasse em fazer do masculino uma força determinada e do feminino uma potência difusa. Exibição exterior, o pelo tem um preconceito masculino: cresce pontualmente, e para fora. Ponto de encontro entre o exterior e o interior, a pele tem um preconceito feminino: é alargada, quase indefinida. Lemonos à flor da pele. Lemos duas mulheres, uma que pinta e outra que escreve. Mas de uma forma indeterminada e fértil, como se a leitura que fazemos fosse a de uma identidade que se encontra ainda em gestação. Santa Teresa de Ávila fala muito dessa alma que vai construindo, como se afinal nascêssemos somente com uma incipiente afirmação do pouco que somos, sendo mais importante o muito que podemos ser.

4.Também aqui se fala do que, ao ver ou ao ler, podemos procurar em outras tantas mais leituras e pinturas e músicas. Nas pinturas de Filomena Vasconcelos, predominam os seres híbridos e os retratos de tempos e espaços contrastantes: a sereia, entre o animal e o humano, os múltiplos olhares na palma da mão, mais do que a linha do destino, os rostos cruzados da enigmática Ilha da Páscoa, as improváveis flores numa chávena de chá, as histórias do dia e da noite, ou sete rostos guardados num só que se inclina... Semelhantemente curiosos são os post-scripti dos contos de Isabel Pereira Leite. A vontade de ir reler a Pequena Sereia, agora "com Sophia por perto". A indicação de que Pearl Buck escreveu "A velha árvore" que nos faz querer dizer, como se fosse nosso, "lembro-me tão bem do prazer que senti ao ler esta história". A proximidade das poesias de Nuno Júdice e as músicas de Wim Mertens e Irving Berlin e o céu à nossa espera. A luz dos olhos de Vinicius que nos fez ouvir Buarque, "quando a luz dos olhos teus e a luz dos olhos meus resolvem se encontrar". E depois Rimsky-Korsakov e Gedeão. E os contos de Cervantes, Caroll, Stevenson, Defoe, Manuel António Pina. E os cantos de Albinoni, Mozart, Bach, Beethoven, Simon \& Garfunkel, Lennon \& McCartney... Nos quadros e nos post-scripti, a mesma gratidão pela diversidade. 
5.É à flor da pele que sentimos. Os pelos do pincel ou da pena são os pequenos sensores de um corpo que não é o nosso mas é o que poderíamos ser se não fossemos só o que somos: o pincel e a pena são o que resta da pele de um animal híbrido, de um poeta pintor ou de um músico poeta que nos conta. Há nos quadros de Filomena Vasconcelos uma diversidade estilística que aceita generosamente escolas diversas: o daltonismo fauvista, a panóptica cubista, o cliché da cultura pop, a simplicidade da pintura "naive", a linearidade da pintura africana, os estilhaços da luz impressionista... Tudo convive, porque tudo nasce naturalmente das mesmas cores primárias da paleta, dos mesmos movimentos básicos do pincel. Há nos contos de Isabel Pereira Leite uma polifonia dos sentidos, que espalha pelos textos sete rostos: a visão, a audição, o tacto, o olfacto, o paladar, a dimensão do tempo, e ainda a da imaginação. E também uma ironia constante, que faz coexistir (a maior parte das vezes, no mesmo conto) um semelhante fascínio pela construção e desconstrução do real que nos é proposto.

6.0 avesso e o direito encadeiam-se num processo que anuncia o eterno retorno do amor e da arte: o amor da sereia pelo mergulhador faz adivinhar uma gloriosa forma de morrer, a morte de um castanheiro centenário é a vida de um quadro e de quem encontrou na pintura a forma de derrotar a morte. É à flor da pela que Xerazade entrelaça as suas histórias. Entre os quadros de Filomena Vasconcelos e os contos de Isabel Pereira Leite existe uma ligação que não é só a que se estabelece entre os quadros e os contos. Como numa tela, a textura é una, ainda que plural seja a direcção do fio. Como se fosse a sequência de um filme, o som do moscardo de um Jardim Encantado confunde-se com o escape da mota de uma Cidade Selvagem. $O$ Paraíso mora na Realidade.

7.Do primeiro ao último quadro, do primeiro ao último texto, há uma ordem disciplinada. Do amor que anuncia a morte se passa para a morte que anuncia o amor, da superioridade do amor idealizado se passa para a superioridade do amor fragmentado, da fragmentação própria dos sentidos se passa para a unidade da vida, da unidade da vida para a hiperbolização do sonho, da hiperbolização do sonho para o mito literário, do mito literário para um sentido de religiosidade, de um sentido de religiosidade para a consciência de uma Natureza animada e sensível, da consciência dessa Natureza para uma ironia sobre a bondade do homem ou da mulher solitários, da ironia da solidão para o elogio da heteronímia, do elogio da 
heteronímia para a subversão dos clichés, da subversão dos clichés para o amor que anuncia o amor...

Quadros e textos evoluem em espiral. Ainda que os nossos passos progridam em eterno retorno, nunca os nossos pés pisarão os mesmos pontos de partida. Conclusão do caminho? Talvez não haja felizmente. A única solução, tão adequada aos posfácios, é simplesmente re-ver, re-ler, para que tudo nos pareça diferente. O pincel aproxima-se da tela. A caneta do papel. Certo é, porém, que "o importante é confiar, mesmo que as respostas para as nossas interrogações não existam".

Porto, 25 de março de 2021

Maria Luísa Malato 

